\title{
¿Es el Tribunal Constitucional EL SUPREMO INTÉRPRETE DE LA CONSTITUCIÓN?**
}

["Is the Constitutional Court the Supreme Interpreter of the Constitution?"]

\author{
Luis Alejandro Silva Irarrázaval** \\ Universidad de los Andes, Santiago, Chile
}

\begin{abstract}
RESUMEN
El artículo examina críticamente la posición del Tribunal Constitucional como máximo intérprete de la Constitución. A través del análisis del diseño y funcionamiento del requerimiento de inaplicabilidad, se pretende demostrar que este mecanismo es un cauce ineficaz de la supremacía interpretativa del Tribunal. Pero, además, se pretende demostrar que esta ineficacia de la inaplicabilidad no responde sólo a un mal diseño o una mala aplicación del requerimiento, sino también y principalmente a ciertos factores intrínsecos a la naturaleza de la Consti-
\end{abstract}

\begin{abstract}
The article critically examines the position of the Constitutional Court as the supreme interpreter of the Constitution. By analyzing the design and operation of the inapplicability requirement it tries to demonstrate that this mechanism is an ineffective channel of the interpretative supremacy of the Court. However, it also tries to demonstrate that this inefficacy of the inapplicability is not just caused by the poor design or a bad application of the requirement, but also mainly due to certain factors inherent to the nature of the Constitution and of the guarantees
\end{abstract}

* Este artículo es resultado del Proyecto Fondecyt de iniciación N 110128: "La supremacía de la Constitución: fundamento y límite de su garantía por el Tribunal Constitucional”, del cual el autor es investigador responsable. Quiero agradecer a los profesores Raúl Bertelsen, Mario Fernández y Hernán Corral la lectura del manuscrito y las sugerencias para mejorarlo.

** Doctor en Derecho por la Universidad de los Andes, Chile. Profesor de Derecho Constitucional de la Facultad de Derecho de la Universidad de los Andes, Chile. Dirección postal: Universidad de los Andes, Facultad de Derecho, Av. San Carlos de Apoquindo 2200, Las Condes, Santiago, Chile. Correo electrónico: 1silva@uandes.cl. 
tución y de su garantía que, en definitiva, impiden la posibilidad de una interpretación definitiva de su contenido.

\section{Palabras Clave}

Tribunal Constitucional - Inaplicabilidad -Interpretación definitiva de la Constitución. granted by it, which ultimately do not allow the possibility of a definite interpretation of its content.

\section{KEYWORDS}

Constitutional Court - Inapplicability - Definite interpretation of the Constitution.

Recibido el 29 de abril y aCEPTAdo el 4 de junio de 2012.

\section{INTRODUCCIÓN}

La eficacia del principio de supremacía constitucional depende de quién sea su custodio. Esto es lo que típicamente se dice cuando se señala al Tribunal Constitucional como el órgano que cumple aquella función. Una característica que es intrínseca a la función de garantizar la supremacía constitucional es el carácter definitivo de la interpretación que haga de ella su guardián. Por eso también se dice que el Tribunal Constitucional tiene la última palabra sobre el significado de la Constitución: es su intérprete definitivo o supremo.

En principio, el Tribunal Constitucional está dotado de los poderes para cumplir su misión. Entre estos poderes tiene el de declarar inaplicable una ley que produce un resultado inconstitucional en su aplicación a un caso concreto. La inaplicabilidad debería confirmar - como casi todas las demás atribuciones del artículo 93 C.Pol.- que el Tribunal Constitucional es el intérprete supremo de la Constitución. Pero no lo hace.

El análisis del requerimiento de inaplicabilidad muestra que el Tribunal Constitucional no es el intérprete último de la Constitución. Y las razones son de diseño: la inaplicabilidad hoy no es apta para servir como cauce de la supremacía interpretativa del Tribunal; pero también son razones intrínsecas al marco conceptual en que se plantea la interpretación suprema de la Constitución. En este segundo orden podría decirse, sencillamente, que la Constitución no admite una interpretación unívoca en Chile.

La exposición del argumento para cuestionar la posición del Tribunal Constitucional como intérprete final de la Constitución, comienza con un desarrollo de las razones con que usualmente se afirma esa posición. La segunda parte aborda específicamente la inaplicabilidad como expresión de la supuesta supremacía del Tribunal Constitucional. La tercera parte muestra los defectos de la inaplicabilidad, de los que brotan serias objeciones a la realidad y a la posibilidad de que el Tribunal Constitucional tenga la 
última palabra sobre el significado de la Constitución. La última parte ofrece dos razones para dudar de que sea posible una interpretación definitiva de la Constitución en Chile.

\section{El Tribunal Constitucional: INTÉRpRete SUPREMO DE LA CONSTITUCIÓN}

La Constitución es la norma suprema del ordenamiento jurídico nacional, pero ¿qué significa esto? Significa varias cosas, complementarias entre sí. Significa principalmente que todos los órganos del Estado deben someter su actuación a ella; que las normas infra-constitucionales son válidas en cuanto se conforman a ella; en que nadie en ninguna circunstancia puede arrogarse derechos o atribuciones que no estén amparados por ella. La enumeración podría ser mayor o diferente, porque hay distintos modos de decir lo mismo.

Pese a la trascendencia de su significado, la supremacía constitucional no es problemática mientras se sostiene en el nivel teórico de los principios. En cambio, cuando se trata de determinar concretamente si la actuación de un órgano estatal es conforme a la Constitución o no lo es; cuando se trata de decidir si una norma legal o administrativa es conforme a la Constitución o no lo es; en fin, cuando se trata de establecer si un derecho o atribución está reconocida en la Constitución o no lo está, entonces la cuestión de la supremacía constitucional se torna polémica. Pero no porque se discuta la supremacía de la Constitución, sino por cuál sea su significado y quién lo declarará.

Interpreta la Constitución quien la aplica. Pero cuando entre quienes aplican la Constitución nace un conflicto acerca de su interpretación, se requiere de alguien que resuelva la diferencia declarando su significado de manera vinculante para las partes en disputa. Como este esquema, en principio, no puede replicarse al infinito, es preciso que haya alguien que dirima con carácter definitivo el significado de la Constitución cuando es objeto de interpretaciones incompatibles. En Chile, esta función se le atribuye ordinariamente al Tribunal Constitucional.

Aunque son muchos los agentes que interpretan la Constitución con carácter jurídico vinculante, el Tribunal Constitucional es el intérprete definitivo. Lo que el Tribunal Constitucional diga a través de sus sentencias sobre el significado de la Constitución, es la última palabra. Ahora bien, las razones para sostener la primacía interpretativa del Tribunal Constitucional son varias. Estas razones, que son parcialmente compatibles entre sí, las clasifiqué en cuatro especies y las desarrollo a continuación. 


\section{Razón lógica.}

En la doctrina nacional dominante existe consenso en que hay un intérprete último o supremo de la Constitución, y que este es un tribunal ${ }^{1}$. En general, las razones -más o menos desarrolladas- que explican la posición de los tribunales respecto de la garantía de la Constitución tienen su matriz en la argumentación de la sentencia "Marbury v. Madison"2: porque la Constitución es norma jurídica suprema y porque las normas jurídicas son definitivamente interpretadas por los tribunales, los tribunales son el intérprete último de la Constitución ${ }^{3}$. En otras palabras, el carácter supremo y normativo de la Constitución implica necesariamente que sea un órgano jurisdiccional su garante máximo ${ }^{4}$.

Según la razón que se está considerando, la naturaleza normativa de la Constitución exige que sea un tribunal quien declare definitivamente su contenido. Pero la naturaleza normativa de la Constitución no precisa qué tribunal deba ser este. Esta segunda cuestión depende de razones políticas.

\section{Razón politica.}

Al calificar como política la razón para justificar la supremacía del Tribunal Constitucional en cuanto intérprete de la Constitución, se quiere significar un motivo que es exigido por razones de conveniencia o prudenciales. No responde a un imperativo lógico y, por lo mismo, su fuerza persuasiva es más débil.

El fundamento político de la supremacía interpretativa del Tribunal

${ }^{1}$ Nogueira, Humberto, La sentencia del Tribunal Constitucional en Chile: análisis y reflexiones juridicas, en Estudios Constitucionales, 8 (2010) 1, pp. 79-116, pp. 101, 103 у 113; Соцомво, Juan, Las sentencias constitucionales: tipología y efectos, en Nogueira, Humberto (coordinador), Jurisdicción constitucional en Chile y América Latina: presente y prospectivas (Santiago, LexisNexis, 2005), pp. 263-291, pp. 275; y 287; Fernández, Miguel Ángel, La sentencia del Tribunal Constitucional, su eventual carácter vinculante y la inserción en las fuentes del Derecho, en Estudios Constitucionales, 4 (2006) 1, pp. 125-149, p. 130; CEA, José Luis, El proyecto de reforma constitucional sobre los efectos de las sentencias del Tribunal Constitucional sobre la justicia ordinaria, en Estudios Constitucionales, 3 (2005) 1, pp. 67-72, pp. 68 y 69.

25 U.S. 137 (1803).

${ }^{3}$ Atria, Fernando, Revisión judicial: el sindrome de la víctima insatisfecha, en Estudios Públicos, 79 (2000), pp. 347-402, pp. 361 y ss. critica este argumento como justificación de la posición del Tribunal Constitucional.

${ }^{4}$ Aldunate, Eduardo, La fuerza normativa de la Constitución y el sistema de fuentes del Derecho, en Revista de Derecho de la Pontificia Universidad Católica de Valparaiso, 32 (2009), pp. 443-484, pp. 444-449 muestra cómo en la doctrina nacional, la idea de la fuerza normativa de la Constitución está íntimamente asociada a su aplicación directa y a su supremacía. Si llega a producirse una confusión o superposición de estas cualidades, se debe tal vez a la escasa precisión conceptual con que se manejan. 
Constitucional puede discutirse en dos niveles. El primer nivel correspondería a la cuestión de por qué el guardián de la Constitución debe ser un tribunal en vez de un órgano político (v. gr. el Congreso). El segundo nivel correspondería a la cuestión de por qué debe ser el Tribunal Constitucional en vez de la Corte Suprema.

En el primer nivel, un presupuesto de la discusión es que la supremacía constitucional no exige que sea necesariamente un tribunal quien declare definitivamente su significado. Es decir, no existe una razón lógica para justificar la garantía jurisdiccional de la supremacía constitucional. Pero políticamente, la tendencia ha sido entregar la custodia de la supremacía constitucional a los tribunales constitucionales (o sus equivalentes), quizá por el recelo que se creó respecto del legislador como garante de los derechos fundamentales, especialmente después de la Segunda Guerra Mundial.

En el segundo nivel, interesan las razones que explican la preferencia por el Tribunal Constitucional en vez de la Corte Suprema. Y estas se encuentran sobre todo en la justificación política para transferir la inaplicabilidad desde la Corte Suprema al Tribunal Constitucional. Quizá la razón más importante para entregar el conocimiento de la inaplicabilidad al Tribunal Constitucional fue la escasa eficacia que el requerimiento tuvo mientras fue competencia de la Corte Suprema ${ }^{5}$. Este motivo se sumó al interés de concentrar el control de constitucionalidad en un solo órgano, asegurando una interpretación más homogénea de la Constitución 6 .

\section{Razón jurídico-normativa.}

Las razones calificadas como jurídico-normativas son las que se deducen del estatuto normativo del Tribunal Constitucional. Aquí se comprenden principalmente las disposiciones legales y constitucionales de naturaleza orgánica y procedimental.

Una primera razón para afirmar la supremacía del Tribunal Constitucional es que controla los actos normativos de los tribunales superiores de justicia (artículo $93 \mathrm{~N}^{\circ} 2$ C.Pol.), del legislador (artículo $93 \mathrm{~N}^{\circ}$ s 1,6 y 7 C.Pol.), del legislador delegado (artículo $93 \mathrm{~N}^{\circ} 4$ ) y del ejecutivo (artículo $93 \mathrm{~N}^{\circ} 16$ C.Pol.) y nadie lo controla a él. Pueden señalarse como expresiones de esta ausencia de control la inexistencia de un superior jerárquico, la imposibilidad de acusar constitucionalmente a los ministros del Tribunal

${ }^{5}$ Puede verse la opinión de Paulina Veloso, entonces ministra Secretaria General de la Presidencia durante la tramitación de la LOTC., en Historia de la reforma de la Ley Orgánica del Tribunal Constitucional, № 20.381 (en adelante, Historia), p. 195.

${ }^{6}$ Puede verse la opinión del Diputado Cristián Monckeberg, en Historia, cit. (n. 5), p. 144 y la indicación de la Senadora Soledad Alvear en Historia, cit. (n. 5), p. 242. 
Constitucional y la imposibilidad de recurrir en contra de sus sentencias (artículo 41 LOTC. $)^{7}$.

Otro argumento que sirve para fundamentar la posición del Tribunal Constitucional como intérprete definitivo de la Constitución, se encuentra en la atribución que tiene para controlar la constitucionalidad de las leyes interpretativas de la Constitución. La interpretación que el legislador hace de la Constitución -que, por lo demás es la ley de quórum más alto- está subordinada a la interpretación que el Tribunal Constitucional haga de la Constitución. Esto puede entenderse como una consecuencia de la posición que tiene el Tribunal entre los intérpretes de la Constitución: está en la cúspide ${ }^{8}$.

La atribución del $\mathrm{N}^{\circ} 7$ del artículo 93 C.Pol. es también un argumento a favor de la supremacía interpretativa del Tribunal Constitucional. En efecto, el poder para declarar inconstitucional un precepto legal y, como consecuencia, eliminarlo del ordenamiento jurídico es equivalente a decir la última palabra en la interpretación constitucional. Porque antes de esta declaración, todos los juicios que se hagan sobre la constitucionalidad de una ley dejan abierta la discusión para el futuro, en cambio el pronunciamiento del Tribunal no, porque la ley deja de existir.

El consenso sobre la posición del Tribunal Constitucional se extiende al valor o carácter de las sentencias que dicta, porque es a través de sus decisiones que hace valer su posición. Esta sentencia sería vinculante para todos los órganos del Estado, porque participaría de la misma jerarquía que la norma interpretada: "la interpretación efectuada por el Tribunal Constitucional sobre el sentido y alcance de los preceptos constitucionales, dentro del marco institucional que le es propio, debe considerarse parte integrante de la propia Constitución y, por ende, vincula directa y obligatoriamente a todos los órganos del Estado, conforme al inciso segundo de su artículo 6"9.

${ }^{7}$ El propio Tribunal Constitucional, en sentencia rol № 1710 , de 6 de agosto de 2010, considerando $42^{\circ}$, lo entiende así: él es el “órgano de cierre del ordenamiento jurídico, pues, junto con interpretar la Carta Fundamental, sus decisiones no pueden ser impugnadas ni revisadas".

${ }^{8}$ Nogueira, Humberto, El control represivo concreto y abstracto de inconstitucionalidad de leyes en la reforma de las competencias del Tribunal Constitucional y los efectos de sus sentencias, en Estudios Constitucionales, 3 (2005) 1, pp. 11-35, p. 17. SAlAzAR, Marta, Interpretación de la Constitución y control de la ley interpretativa por el Tribunal Constitucional, en Revista Chilena de Derecho, 20 (1993) 2-3, pp. 467-473.

${ }^{9}$ Carreño, Gonzalo - JaraQuemada, Jorge, La fuerza vinculante de las sentencias constitucionales y el reconocimiento de derechos fundamentales. A propósito de la ley sobre regulación de la fertilidad, en Revista Chilena de Derecho, 37 (2010), pp. 405-419, p. 413. No explican los autores por qué debe considerarse la sentencia parte integrante de la propia Constitución. La misma idea en p. 416. Un criterio similar puede 
El artículo 94 C.Pol. parece confirmar esta cualidad de las sentencias del Tribunal Constitucional, porque estaría reconociéndolas como la última palabra. Serían, por lo tanto, obligatorias, porque no procede contra ellas recurso alguno ${ }^{10}$. El artículo 51 LOTC., que replica el artículo 83 C.Pol., antes de la reforma de 2005, y 37 LOTC. antes de la última reforma, es también un argumento favorable al efecto vinculante de las sentencias del Tribunal Constitucional, porque en determinadas circunstancias lo decidido por ellas no puede volver a discutirse ${ }^{11}$. Por último, el efecto vinculante de las sentencias descansaría en las mismas Bases de la Institucionalidad ${ }^{12}$.

El carácter vinculante de la sentencia del Tribunal Constitucional se presenta como una consecuencia exigida por su posición de último intérprete de la Constitución: "el efecto vinculante de las sentencias [...] no sólo opera respecto de él mismo sino que de todo el resto de los órganos del Estado que deben ajustarse a la interpretación y los criterios por él manifestados en cuanto guardián supremo de la Constitución"13.

Como se puede ver, del estatuto normativo del Tribunal Constitucional es dable concluir la supremacía interpretativa que este órgano tiene respecto de la Constitución. Con razón Cumplido calificó al Tribunal Constitucional después la reforma de 2005 como un "super-poder" 14 . A estas razones de texto, pueden añadirse algunos hechos que las confirman.

deducirse en Zapata, Patricio, Justicia Constitucional. Teoría y Práctica en el Derecho chileno y comparado (Santiago, Editorial Jurídica de Chile, 2008), p. 370: "la solución puntual contenida en un fallo, en la medida que anticipa o augura soluciones similares en lo futuro, deviene en norma a la cual deberán ceñirse los órganos colegisladores si pretenden actuar en el ámbito de la validez constitucional”. En idéntico sentido, aunque menos explícitamente, CEA, José Luis, La jurisdicción constitucional, en Revista de Derecho de la Universidad Finis Terrae, 10 (2006), pp. 11-19, p.18: "Los pronunciamientos de la Justicia Constitucional [...] tienen que ser siempre acatados [...]. Es el efecto propio de la supremacía constitucional, cuyo intérprete máximo es la Justicia Constitucional".

${ }^{10}$ Fernández, Miguel Ángel, cit. (n. 1), pp. 142-143.

${ }^{11}$ Es la lectura que hizo Bulnes del antiguo artículo 83 C.Pol.: Bulnes, Luz, Efectos de las sentencias de la jurisdicción constitucional en la judicatura ordinaria, en Estudios Constitucionales, 3 (2005) 1, pp. 55-65, p. 57. En un sentido parcialmente diverso, pero útil a esta tesis: Fermandois, Arturo, Efecto vinculante de las sentencias del Tribunal Constitucional: ¿mito o realidad?, en ZúÑIGA, Francisco (coordinador), Reforma Constitucional (Santiago, LexisNexis, 2005), pp. 685-696, p. 689.

${ }^{12}$ Bulnes, Luz, cit. (n. 11), p. 58 ss; Carreño, Gonzalo - Jaraquemada, Jorge, cit. (n. 9), p. 413; Fermandois, Arturo, Efecto, cit. (n. 11), pp. 691 ss.

${ }^{13}$ PEÑA, Marisol, El precedente constitucional emanado del Tribunal Constitucional y su impacto en la función legislativa, en Estudios Constitucionales, 4 (2006) 1, pp. 173184, p. 181.

${ }^{14}$ Cumplido, Francisco, Reforma constitucional y régimen politico, en ZÚÑIGA, 


\section{Razón "empirica”.}

En este apartado se han reunido las razones que de hecho demuestran la supremacía interpretativa del Tribunal Constitucional. Como no podía ser de otra manera -y vuelvo sobre ello al final de este artículo- las pruebas que aquí se ofrecen son de valor relativo.

Quizá la mejor demostración de la posición del Tribunal Constitucional como intérprete final de la Constitución es el efecto de sus sentencias. Un caso que motivó una polémica amplia en torno al poder del Tribunal fue la sentencia rol No 740, conocida también como "Píldora II", que declaró la inconstitucionalidad parcial del Decreto supremo $\mathrm{N}^{\circ} 48$ del Ministerio de Salud. Esta sentencia produjo reacciones encontradas en la doctrina, que disputaron precisamente acerca del alcance de la interpretación del Tribunal Constitucional ${ }^{15}$. El propio Tribunal definió su potestad: "tanto los órganos del Estado, como toda persona, institución o grupo se encuentran en el imperativo de acatar la decisión del Tribunal Constitucional, porque ha ejercido

Francisco (coordinador), Reforma Constitucional (Santiago, LexisNexis, 2005), pp. 113-124, p. 120.

${ }^{15}$ Delaveau, Rodrigo, Fallo del Tribunal Constitucional sobre la pildora del día después. Paternalismo y la dificultad contramayoritaria, en Actualidad Jurídica, 18 (2008), pp. 55-68 defiende la legitimidad del Tribunal Constitucional para decir la última palabra; ZúñıgA, Francisco, [Comentario a la sentencia rol 740 del Tribunal Constitucional], en Revista de Derecho Público, 70 (2008), pp. 471-487, p. 484 aprovecha la sentencia para recordar que el Tribunal Constitucional es el guardián supremo de la Constitución; Carreño, Gonzalo - Jaraquemada, Jorge, cit. (n. 9); y FundaCIÓN JaIme GuZmán, A propósito del proyecto de ley sobre regulación de la fertilidad: la fuerza del precedente constitucional, en Ideas y Propuestas, 24, (22 de julio de 2009), pp. 1-11 critican al legislador, porque habría contrariado la definición del Tribunal Constitucional al dictar la ley 20.418. Jiménez, Guillermo - Marshall, Pablo, La píldora del día después y las potestades públicas, en Hemiciclo, 1 (2010) 2, pp. 45-66, pp. 60-64 discuten la decisión, porque el Tribunal Constitucional no es el intérprete supremo de la Constitución y, sin embargo, actuó como si lo fuera; Bordalí niega a las sentencias del Tribunal todo efecto vinculante de la interpretación que contengan, porque no es el intérprete supremo, en AA.VV., Sentencia sobre inconstitucionalidad del Decreto Supremo $N^{\circ} 48$ del Ministerio de Salud en la parte que autoriza la distribución de la "pildora del día después" en el sistema público de salud (Tribunal Constitucional), en Revista de Derecho de la Universidad Austral de Chile, 21 (2008) 1, pp. 155-170, p. 169; NASH, Claudio - IrarRázabal, Paz, Justicia constitucional en Chile y protección de los derechos fundamentales, en BAZÁN, Víctor - NASH, Claudio (editores), Justicia constitucionaly derechos fundamentales. Aportes de Argentina, Bolivia, Brasil, Chile, Perú, Uruguay y Venezuela 2009 (Santiago, Konrad Adenauer Stiftung y Centro de Derechos Humanos de la Facultad de Derecho de la Universidad de Chile), pp. 55-67, disponible en http://www.cdh.uchile.cl/libros/Libro_Justicia_Constitucional.pdf, p. 58 destacan la posición central del Tribunal en el sistema de justicia constitucional que esta sentencia puso en evidencia. 
la tarea que el propio Constituyente le ha confiado de velar por la supremacia, sustantiva y formal, de la Carta Fundamental" ${ }^{16}$.

La Contraloría General de la República confirmó la posición del Tribunal Constitucional, al resolver una consulta que se le planteó acerca del alcance de la sentencia rol No 740 . En su Dictamen $\mathrm{N}^{\circ} 31.356$, de 16 de junio de 2009, reconoció la calidad de intérprete supremo de la Constitución que tiene el Tribunal Constitucional y, en consecuencia, el valor de sus sentencias. Concretamente dijo que ellas fijan los límites interpretativos de la Constitución para todos los operadores jurídicos, su acatamiento es obligatorio y constituye una peculiar fuente del derecho ${ }^{17}$.

Más tarde serán los tribunales superiores de justicia los que, con ocasión del mismo caso, tendrían ocasión de pronunciarse sobre el efecto de las sentencias del Tribunal Constitucional. Cuando la Corte de Apelaciones rechazó el recurso de protección interpuesto contra el Dictamen $\mathrm{N}^{\circ}$ 31.356 de la Contraloría General de la República, dijo que ningún órgano del Estado puede "formular interpretaciones o hacer aclaraciones a lo fallado por la Magistratura Constitucional [...] sino tan solo cumplir lo resuelto por ella"18. Esta misma idea de la obligatoriedad de las sentencias del Tribunal Constitucional para toda persona, institución o grupo la repitió en los considerandos $35^{\circ}$ y $36^{\circ}$.

Las conclusiones que se extraen de la sentencia "Píldora II" acerca del valor de la interpretación que el Tribunal Constitucional hace de la Constitución, pueden extenderse a las declaraciones de inconstitucionalidad que ha hecho en virtud del artículo $93 \mathrm{~N}^{\circ}$. Porque también en estos casos la interpretación del Tribunal Constitucional ha predominado sobre la interpretación legal y judicial ${ }^{19}$. Ilustra bien el punto la negativa de la Corte Suprema a pronunciarse

${ }^{16}$ Sentencia del Tribunal Constitucional rol No 740 , de 18 de abril de 2008, considerando $70^{\circ}$. Antes, con motivo del requerimiento de constitucionalidad contra la resolución exenta $\mathrm{N}^{\circ} 584$ que aprobaba normas sobre regulación de la fertilidad (el antecedente del Decreto Supremo $\mathrm{N}^{\circ} 48$ ), el Tribunal declaró que a él le ha sido encomendada "la interpretación definitiva e inapelable de la Constitución [...] a fin de asegurar la vigencia efectiva de la supremacía constitucional" (sentencia del Tribunal Constitucional No 591, de 11 de enero de 2007, considerando $3^{\circ}$ ). Bordalí realiza un sugerente análisis del considerando $70^{\circ}$ de la sentencia del Tribunal Constitucional $\mathrm{N}^{\circ}$ 740, AA.VV., Sentencia, cit. (n. 28).

${ }^{17}$ Jiménez, Guillermo - Marshall, Pablo, cit. (n. 15) critican este dictamen.

18 "Vera Flores con Subcontralora General de la República", recurso de protección fallado por la Corte de Apelaciones de Santiago, 29 de octubre de 2009, rol No 8777 09. Confirmado por la Corte Suprema, 6 de enero de 2010, rol No 8157-2009.

${ }^{19} \mathrm{La}$ sentencia del Tribunal Constitucional No 1710, de 6 de agosto de 2010, que declaró la inconstitucionalidad parcial del artículo 38 ter de la ley de Isapres, definió en su considerando $40^{\circ}$ que la supremacía constitucional implica que las sentencias del 
sobre la constitucionalidad del artículo 116 C.Trib., después de que este fue derogado por la sentencia rol No 681, de 26 de marzo de 2007, porque el Tribunal Constitucional es el "unico contralor de la regularidad de las leyes"20.

Revisadas las razones que, en general, pueden darse para justificar la posición del Tribunal Constitucional respecto de la Constitución, quiero ahora examinar de cerca el requerimiento de inaplicabilidad, como una particular razón que confirma la supremacía interpretativa del Tribunal. Y esto porque la inaplicabilidad es la atribución que más ejercita el Tribunal de todas las que le reconoce el artículo 93 C.Pol. ${ }^{21}$.

\section{LA INAPLICABILIDAD: CAUCE IDÓNEO DE LA SUPREMACÍA inTERPRETATIVA DEL Tribunal Constitucional}

Al entregar el conocimiento de los requerimientos de inaplicabilidad al Tribunal Constitucional, la reforma de 2005 estableció la primacía de este tribunal respecto del resto de los tribunales de la República, en cuanto a la interpretación de la Constitución ${ }^{22}$. Así es como lo ha entendido Cea ${ }^{23}$, el Tribunal Constitucional ${ }^{24}$ y los propios tribunales superiores de justicia ${ }^{25}$.

Tribunal Constitucional deben observarse por parte de los titulares e integrantes de los órganos del Estado y por toda persona, institución o grupo.

${ }^{20}$ Por todas, "SII con No se consigna", casación en la forma y el fondo resuelta por la Corte Suprema, 19 de diciembre de 2011, rol No 8424-09.

${ }^{21}$ Como referencia, puede verse la tabla estadística correspondiente a los años 20062008 en la Memoria 2007-2008 del Tribunal Constitucional, disponible en http://www.tribunalconstitucional.cl/index.php/documentos/downloadpdf/301, pp. 45 y ss.

${ }^{22}$ Cоцомво, Juan, El requerimiento de inaplicabilidad ante el Tribunal Constitucional, en Temas Actuales de Derecho Constitucional (Santiago, Editorial Jurídica de Chile, 2009), pp. 53- 74, pp. 57 y 58.

${ }^{23}$ CEA, José Luis, El proyecto, cit. (n. 1), p. 68-69. También NúÑEz, Manuel, El control de la igualdad en la aplicación de la ley como factor de expansión del control concreto de constitucionalidad de las leyes, en Sentencias Destacadas 2007, (Santiago, Instituto Libertad y Desarrollo, 2008), pp. 123-161, pp. 154-155.

${ }_{24}$ "Que uno de los fundamentos para traspasar la acción de inaplicabilidad de la $\mathrm{H}$. Corte Suprema a este Tribunal, supremo guardián de la Constitución y no perteneciente al Poder Judicial, fue concentrar en este especialísimo órgano el control de constitucionalidad": sentencia del Tribunal Constitucional rol № 1191, de 19 de mayo de 2009, considerando $7^{\circ}$. Otro ejemplo es la sentencia del Tribunal Constitucional rol № 591, de 11 de enero de 2007, considerando $3^{\circ}$ : es al Tribunal Constitucional a quien se le ha encomendado la "interpretación definitiva e inapelable de la Constitución"; y la sentencia del Tribunal Constitucional rol No 2025, 20 de julio de 2011, considerando $17^{\circ}$, que remite al considerando $3^{\circ}$ de la sentencia del Tribunal Constitucional $\mathrm{N}^{\circ}$ rol 591.

25 "SII con No se consigna", casación en la forma y el fondo resuelta por la Corte Suprema, 19 de diciembre de 2011, rol No 8424-09. 
Esta nueva atribución del Tribunal Constitucional lo coloca como intérprete definitivo de la Constitución, con la consecuencia de que los jueces quedan impedidos de aplicar la norma declarada inaplicable (al menos en un determinado sentido); y en apelación o casación los jueces deberán revocar o casar la sentencia que aplicó el precepto declarado inaplicable ${ }^{26}$.

A través del requerimiento de inaplicabilidad, el Tribunal cumple su función de garante final de la supremacía constitucional ${ }^{27}$. Concretamente, hay dos manifestaciones características de la inaplicabilidad que permiten afirmar su idoneidad para servir de cauce a la supremacía interpretativa del Tribunal Constitucional. Una es el efecto que sus sentencias tienen en la gestión pendiente, por lo que más de uno las ha proclamado como supercasatorias. La otra es la exclusión de la ley como parámetro de enjuiciamiento: a través de la inaplicabilidad sólo se interpreta y aplica la Constitución.

\section{La inaplicabilidad como super-casación.}

Francisco Zúñiga ha dicho que el Tribunal Constitucional deviene en "tribunal de super-casación", por los efectos que sus sentencias de inaplicabilidad tienen en la decisión del tribunal que conoce de la gestión pendien$t^{28}$. Después de él otros se han sumado a esta caracterización del Tribunal Constitucional o de sus sentencias de inaplicabilidad ${ }^{29}$. ¿Qué se quiere decir cuándo se utiliza esta expresión?

Propiamente hablando, el efecto de casar es sinónimo de anular, y se predica de las sentencias de la Corte Suprema que tienen el poder para anular resoluciones de los tribunales inferiores por defectos de forma y fondo. El

${ }^{26}$ ZúñIga, Francisco, Acciones de inaplicabilidad e inconstitucionalidad. Doctrina y jurisprudencia del Tribunal Constitucional sobre temas procesales (Santiago, LegalPublishing, 2010), p. 29.

${ }^{27}$ Bronfman, Alan, El carácter privado del proceso de inaplicabilidad por inconstitucionalidad, en Revista de Derecho de la Pontificia Universidad Católica de Valparaíso, 37 (2011), pp. 243-274, p. 272 concluye que lo más adecuado es concebir la inaplicabilidad "como una especie de litigación pública al servicio del interés de la supremacía de la Constitución”.

${ }^{28}$ ZúÑIGa, Francisco, Control de constitucionalidad y sentencia (Santiago, Cuadernos del Tribunal Constitucional 34, 2006), p. 15; ZúÑ̃ IgA, Francisco, Acción de inaplicabilidad por inconstitucionalidad: requerimiento de jueces entre legalidad y constitucionalidad, en Revista de Derecho Público, 72 (2010), pp. 294-339, p. 308.

${ }^{29}$ Couso, Javier - Coddou, Alberto, La naturaleza jurídica de la acción de inaplicabilidad en la jurisprudencia del Tribunal Constitucional: un desafio pendiente, en Estudios Constitucionales, 8 (2010) 2, pp. 389-430, p. 412; SkoknIC, Ivo, Justicia Constitucional, (2009), disponible en http://www.westlaw.cl; NúÑEZ, Manuel, cit. (n. 23), p. 155. 
Tribunal Constitucional no tiene el poder para anular sentencias, ¿̨por qué entonces se afirma que es un tribunal de super-casación?

La casación es un recurso que se interpone ante la Corte Suprema en su calidad de órgano superior del Poder Judicial; la de casar sentencias es una facultad atribuida al órgano que pronuncia la última palabra sobre el significado de la ley. Por analogía, se dice que el Tribunal Constitucional es un tribunal de super-casación, porque interpreta definitivamente la Constitución como la Corte Suprema interpreta definitivamente la ley. Pero también por una razón próxima a ésta se caracteriza al Tribunal Constitucional como un tribunal de super-casación: "el Tribunal Constitucional se erige en un tribunal de super-casación; y funcionalmente hablando, supraordenado al Poder Judicial y a la Justicia Electoral, en el sentido que, en lo que respecta al control de constitucionalidad de una norma legal, la única y última palabra la tiene el Tribunal Constitucional"30.

Se dice que el Tribunal Constitucional es super-casatorio no sólo por la analogía que guarda con la Corte Suprema, sino también porque las sentencias de inaplicabilidad fijan el sentido en que los demás tribunales deben interpretar la Constitución. En otras palabras, el Tribunal Constitucional está en una posición superior a la Corte Suprema, que replica la superioridad que la Constitución tiene sobre la ley.

Un punto controvertido en relación a la posición que el Tribunal Constitucional tiene respecto de los demás tribunales -de su supremacía, por tanto-, es la aptitud de la inaplicabilidad para controlar las resoluciones judiciales. La disputa es compleja y no quiero abordarla aquí. Más adelante se hará, pero indirectamente y en la medida que resulte útil al foco de esta investigación. Lo que ahora me interesa destacar es la contradicción que, al menos en apariencia, significa llamar super-casatorio al efecto de las sentencias de inaplicabilidad y rechazar la aptitud de la inaplicabilidad para controlar las resoluciones judiciales. Si se afirma lo primero, debe aceptarse lo segundo.

En verdad no es posible al Tribunal Constitucional evitar un juicio sobre las resoluciones judiciales a través de la inaplicabilidad. Por lo tanto, debería concluirse que el Tribunal es efectivamente super-casatorio. Aunque la explicación se desarrolla más adelante, el enunciado es el siguiente: cuando se requiere de inaplicabilidad desde un juicio en el que ha existido un pronunciamiento del juez, el Tribunal Constitucional no puede prescindir de la interpretación judicial del precepto legal para decidir la inaplicabilidad. Podría declarar inadmisible el requerimiento, recurriendo a la doctrina de las "cuestiones de mera legalidad" ${ }^{11}$, pero si lo admite, inevitablemente la

\footnotetext{
${ }^{30}$ ZÚÑIga, Francisco, Acciones, cit. (n. 26), p. 29.

${ }^{31}$ ZúNíga, Francisco, Acciones, cit. (n. 26), p. 138 entiende que esta doctrina es
} 
sentencia incluirá un juicio sobre la interpretación judicial confirmándola, tolerándola o rectificándola. En cualquiera de estos casos, el Tribunal Constitucional actuará como un tribunal de super-casación ${ }^{32}$.

Es una tendencia cada vez más patente la de requerir la intervención del Tribunal Constitucional a través de la inaplicabilidad para obtener una sentencia favorable que resulta esquiva en los tribunales ordinarios. El caso del artículo 38 ter de la Ley de Isapres es bien ilustrativo al respecto. En cuanto se dictó la primera sentencia que declaró inaplicable por inconstitucional la disposición que permitía subir el precio del plan de salud en consideración al sexo y la edad, una cantidad ingente de causas se presentaron para obtener del Tribunal Constitucional lo que la Corte Suprema les negaba: la inconstitucionalidad de la tabla de factores. Por esto se ha afirmado que "el control concreto [de constitucionalidad] de las leyes se ha transformado, en los hechos, en una nueva y última instancia judicial"33.

Caracterizar al Tribunal Constitucional como uno de super-casación es coherente con afirmar la supremacía que tiene para interpretar la Constitución. No parece posible defender, por una parte, la predominancia de su interpretación por sobre las demás interpretaciones y negar, por otra parte, que carezca de competencia para controlar cómo los tribunales de justicia aplican la Constitución. Núñez es coherente en este punto y, así como afirma que el Tribunal Constitucional es el intérprete supremo de la Constitución, afirma que a través de la inaplicabilidad "se ha convertido en un contralor especial de la aplicación de la ley y, por lo tanto, de la función jurisdiccional"34.

¿Cómo salvar la aparente incompatibilidad entre reconocer la función super-casatoria del Tribunal Constitucional y defender la competencia propia de los tribunales de justicia? Porque es obvio que al admitir un efecto casatorio en las sentencias de inaplicabilidad, se está alterando el diseño institucional de la administración de justicia, por lo menos. La respuesta para superar esta supuesta incompatibilidad se afirma en la diferencia entre aplicar la ley y aplicar la Constitución. La ley y la Constitución son distintas y tienen sus propios y específicos ámbitos de aplicación. La Corte Suprema vela por

una de las formas en que el Tribunal Constitucional limita el efecto super-casatorio de sus sentencias

${ }^{32}$ SkoKNIC, Ivo, cit. (n. 29) entiende que por la vía de juzgar la interpretación que los tribunales hacen del precepto requerido de inaplicabilidad, el Tribunal Constitucional se va transformando en un verdadero tribunal de casación constitucional.

${ }^{33}$ Nash, Claudio - Irarrázabal, Paz, cit. (n. 15), p. 57.

${ }^{34}$ NúÑ̃E, Manuel, cit. (n. 23), p. 155. HormazáBAL, Hernán, El nuevo Tribunal Constitucional (Santiago, LexisNexis, 2006), pp. 53-54 entiende que la inaplicabilidad comporta la competencia para juzgar una determinada interpretación de la ley e instituye al Tribunal Constitucional como "el intérprete máximo de la Constitución junto con el legislador". 
la correcta aplicación de la ley y el Tribunal Constitucional por la correcta aplicación de la Constitución. El mismo Tribunal Constitucional descartó la contradicción entre la justicia constitucional y la ordinaria, al afirmar que se trata "de jurisdicciones muy diversas: una es la constitucional, referida a la supremacia de la Constitución; la otra, vinculada a la facultad de conocer las causas civiles o criminales, de resolverlas y hacer ejecutar lo juzgado, entregada exclusivamente a los tribunales establecidos por la ley"35. Para Zúñiga, la concentración del control de constitucionalidad en el Tribunal Constitucional después de la reforma de 2005, reforzó la función de la Corte Suprema como corte de casación, al cerrar la posibilidad de invocar la Constitución a través del recurso de casación. En otras palabras, la reforma separó "la sumisión a la Constitución y la sumisión a la ley por parte de los tribunales, velando por los principios de constitucionalidad y el principio de legalidad y sus controles respectivos (control de constitucionalidad y casación)"36. Esto significa que el requerimiento de inaplicabilidad no interfiere en la competencia de los tribunales de justicia, porque a través suyo solo se aplica la Constitución.

\section{La inaplicabilidad sólo interpreta/aplica la Constitución.}

El Tribunal Constitucional es el guardián de la supremacía de la Constitución, no de la ley. Su función es velar por la correcta aplicación de la Constitución y para ello se le ha constituido como su intérprete definitivo. Los instrumentos con que cuenta son idóneos a la función que está llamado a desempeñar. Concretamente, la inaplicabilidad es un mecanismo para asegurar que la aplicación de la ley en un caso particular resulta conforme con la Constitución. El Tribunal Constitucional ha tenido ocasión de afirmar rotundamente que "El parámetro de referencia que se tiene en cuenta al resolver una inaplicabilidad, es sólo la Constitución" ${ }^{37}$. Por esto, no le compete pronunciarse sobre la correcta interpretación de la ley "si no es con relación a su constitucionalidad"38.

El ministro Enrique Navarro compendia una serie de criterios que delimitan el ámbito específico de la inaplicabilidad. La inaplicabilidad no es apta para impugnar el razonamiento contenido en una decisión judicial, ni para estimar cuál sea la decisión judicial más adecuada, ni para corregir la

\footnotetext{
${ }^{35}$ Sentencia del Tribunal Constitucional rol No 1615, de 20 de enero de 2011, considerando $7^{\circ}$.

${ }^{36}$ ZúñIga, Francisco, Control, cit. (n. 28), p. 19; ZúÑIGA, Francisco, Acción, cit. (n. 28), p. 312 .

${ }^{37}$ Sentencia del Tribunal Constitucional rol No 1284, de 24 de septiembre de 2009, considerando $5^{\circ}$.

${ }^{38}$ Sentencia del Tribunal Constitucional rol No 810 , de 24 de enero de 2008, considerando $9^{\circ}$.
} 
eventual infracción de ley por parte de un tribunal, ni para determinar el tipo de relación jurídica entre un funcionario y la Administración, ni para establecer la forma correcta de computar un plazo, ni para aclarar el sentido de un tipo penal, ni para resolver el conflicto entre la decisión de una autoridad y la ley, ni para fijar la correcta interpretación de la ley, ni para pronunciarse sobre la norma decisoria litis, ni para declarar la vigencia, validez o existencia de un precepto legal ${ }^{39}$.

El Tribunal Constitucional es consciente de su poder y del riesgo que supone su ejercicio para la competencia específica de los tribunales de justicia. Por eso se restringe, fijando los límites de lo que puede pedirse a través de la inaplicabilidad. Un ejemplo es el considerando $13^{\circ}$ de la sentencia rol No 481, de 4 de julio de 2006: "no cabe utilizar la vía de la inaplicabilidad como un medio que persiga enmendar lo ya resuelto por un tribunal en un caso concreto y que se ha materializado a través de una resolución judicial" 40 . Una parte importante de estos criterios de restricción de la inaplicabilidad podrían agruparse bajo el alero de la doctrina de las cuestiones de legalidad, que opera en el juicio de admisibilidad de los requerimientos.

La LOTC. enumera varias causales de inadmisibilidad de estos requerimientos, que el Tribunal Constitucional con su jurisprudencia va precisando en cuanto a su sentido y alcance. Dos de estas causales (dirigir el requerimiento contra algo distinto de un precepto legal y la carencia de fundamento razonable del requerimiento) han servido repetidas veces para rechazar la tramitación de requerimientos que versan sobre "cuestiones de legalidad". Generalmente, estas "cuestiones de legalidad" son -a juicio del Tribunal- discusiones sobre la interpretación judicial de ley. Y esta es materia ajena a la competencia del Tribunal, que recae sobre "cuestiones de constitucionalidad".

La doctrina de las cuestiones de legalidad y cuestiones de constitucionalidad refleja la diferencia que existe entre la ley y la Constitución, y enfatiza la función propia del Tribunal Constitucional, que es aplicar la Constitución,

${ }^{39}$ Navarro, Enrique, El control de constitucionalidad de las leyes en Chile (18112011) (Santiago, Cuadernos del Tribunal Constitucional, 43, 2011), pp. 67-73. Me abstengo de citar las sentencias respectivas, porque todas pueden consultarse en el libro. Para un repertorio más amplio, puede consultarse Enrique Navarro - Carlos Carmona (editores), Recopilación de jurisprudencia del Tribunal Constitucional (1981-2011) (Santiago, Cuadernos del Tribunal Constitucional, 2011), pp. 486-492.

${ }^{40}$ Martínez, José Ignacio, La cuestión de inaplicabilidad como mecanismo de control de la interpretación de preceptos legales, en Romero, Alejandro - MARTínez, José Ignacio - Arancibia, Jaime (coordinadores), Litigación pública (Santiago, AbeledoPerrot-ThomsonReuters, 2011) pp. 375-396, p. 386 entiende esta actitud del Tribunal como expresión del principio de deferencia razonada, que vale tanto respecto de los jueces como del legislador. 
no la ley. Esta doctrina es consistente con la supremacía interpretativa de la Constitución que tiene el Tribunal Constitucional, porque en las cuestiones de legalidad la supremacía interpretativa es de los tribunales de justicia.

La separación entre las cuestiones de legalidad y de constitucionalidad (entre ley y Constitución) no es fácil, pero en principio es posible. La dificultad de distinguir de qué cuestión se trata (si de legalidad o de constitucionalidad) estriba en acomodar el criterio a las circunstancias de cada caso. Porque el criterio para reconocer las materias propias del Tribunal Constitucional es claro: la (eventual) infracción de la Constitución; pero las circunstancias de cada caso son cambiantes, y siempre cabe la posibilidad de criticar su aplicación, porque se estimó como de constitucionalidad lo que era de legalidad o viceversa ${ }^{41}$. De todos modos, esto no debería significar una objeción a la supremacía interpretativa del Tribunal Constitucional, sino una demostración de lo delicado que es el ejercicio de su tarea.

Para cerrar esta sección y a modo de síntesis, interesa destacar la relación que se da entre la posición del Tribunal Constitucional como intérprete supremo de la Constitución, el alcance exclusivamente constitucional de la inaplicabilidad y la distinción real entre los ámbitos de la legalidad y de la constitucionalidad: es una relación de dependencia que se apoya en esta última distinción. Si la Constitución y la ley no pudieran aplicarse separadamente, entonces no podría afirmarse que la inaplicabilidad sólo aplica la Constitución y, en consecuencia, tampoco podría afirmarse que esta es definitivamente interpretada por el Tribunal Constitucional, sin alterar el diseño institucional de administración de justicia ${ }^{42}$.

\section{LA INAPLICABILIDAD NO ES CAUCE IDÓNEO DE LA SUPREMACÍA INTERPRETATIVA DEL TRIBUNAL CONSTITUCIONAL}

Hasta aquí, se han desarrollado los argumentos que sostienen la supremacía interpretativa del Tribunal Constitucional. Pero cada uno de estos argumentos tiene un punto débil, que relativiza la posición del Tribunal como intérprete supremo. Esta segunda mitad del trabajo revisa críticamente esos argumentos. Primero, los que se refieren a la inaplicabilidad, porque así como se vio que servían para confirmar al Tribunal Constitucional en su función de intérprete supremo, ahora se verá cómo sirven exactamente para

${ }^{41}$ Ejemplos de estas críticas en Martínez, José Ignacio, cit. (n. 40), p. 395 y ALDUNATE, Eduardo, Jurisprudencia constitucional 2006-2008. Estudio selectivo, (Santiago, LegalPublishing, 2009), p. 15-16.

${ }^{42}$ ZúNiga, Francisco, Acción, cit. (n. 28), p. 323 asume la distinción entre legalidad y constitucionalidad como condición funcional para la legitimidad democrática de la jurisdicción constitucional. 
lo contrario. Segundo, los que se refieren en general a la calidad del Tribunal como guardián último de la supremacía constitucional.

Respecto de la inaplicabilidad, las objeciones son básicamente dos y se dirigen a demostrar que esta vía no es un cauce idóneo de la supremacía interpretativa del Tribunal Constitucional. El primero quiere mostrar que las sentencias de inaplicabilidad son inútiles en la práctica: un instrumento que no sirve (o sirve mal) para cumplir la función que justifica su existencia. El segundo pretende probar que la inaplicabilidad no actúa en el ámbito exclusivamente constitucional, sino que a través suyo se interpreta la ley.

\section{Las sentencias de inaplicabilidad son inútiles.}

La eficaz garantía de la Constitución depende de la eficacia de las actuaciones de su guardián: si las sentencias de inaplicabilidad son inútiles en la práctica, entonces el Tribunal Constitucional no es de hecho el supremo intérprete de la Constitución. Pero, ¿qué significa útil/inútil en este contexto? Lo útil se predica de lo que sirve para alcanzar el fin con el que se usa. Una cosa puede ser inútil -entre otras razones- por su diseño (un reloj al que le falta un resorte) o por su uso (palillos chinos para tomar la sopa). Aquí se sostiene que la inaplicabilidad es inútil porque hay un error en el diseño.

a) El mal diseño de la inaplicabilidad. La inaplicabilidad está concebida para evitar que un precepto legal se aplique en un juicio (gestión pendiente, si se quiere) con un resultado contrario a la Constitución. Pero ni la Constitución ni la Ley orgánica del Tribunal Constitucional precisan el momento en que la aplicación que motiva el requerimiento debe producirse. Y como no se precisa, se ha entendido que cualquier momento de la gestión es oportuno para plantear la inaplicabilidad. Y aquí está el primer error de diseño que torna prácticamente inútiles las sentencias del Tribunal Constitucional.

Puesto que el requerimiento de inaplicabilidad puede plantearse en cualquier momento de la gestión que se tramita ante los tribunales, existe la posibilidad de que la sentencia se dicte antes de que el tribunal se pronuncie sobre el significado de la ley que fue objeto del requerimiento ${ }^{43}$. Esto no significa que la sentencia será necesariamente inútil, porque en principio el tribunal quedaría impedido de aplicar la ley declarada inaplicable. Pero puede ser inútil en el caso de las sentencias "interpretativas", es decir, las sentencias que declaran inaplicable el precepto legal "en el entendido que",

${ }^{43}$ CORREA, Jorge, Inaplicabilidad por inconstitucionalidad en la jurisprudencia del Tribunal Constitucional (Santiago, AbeledoPerrot, 2011), pp. 63 y 66 reconoce el problema que esta situación supone para el valor de la interpretación que hace el Tribunal Constitucional. 
porque entonces puede ser aplicado en un sentido distinto ${ }^{44}$. También puede ser inútil si la acción con que se inició el juicio se declara inadmisible ${ }^{45}$. Además, la oportunidad para requerir de inaplicabilidad puede hacer inútiles sus sentencias, porque no se ha determinado el derecho aplicable al caso ${ }^{46}$ o porque en muchos casos las sentencias de los tribunales, exceptuando la Corte Suprema, pueden ser enmendadas por sus superiores jerárquicos ${ }^{47}$. Este defecto del diseño de la inaplicabilidad está determinado por el carácter inevitablemente prospectivo que tiene el juicio de inconstitucionalidad practicado a través suyo ${ }^{48}$.

${ }^{44}$ Esta posibilidad no inutiliza necesariamente el efecto práctico de la sentencia, pero deja un margen para que la ley produzca igual un resultado contrario a la Constitución. Correa, Jorge, cit. (n. 43), p. 59 alude a la precaria situación del Tribunal en los casos que desestima un requerimiento bajo la condición de que el precepto impugnado se interprete en un determinado sentido, porque no tiene nada que hacer si luego los jueces de fondo dan al precepto la interpretación que resultaba contraria a la Constitución. Fue el caso de los jueces de garantía y la interpretación del artículo 186 CPP. Lo mismo podría ocurrir cuando la inaplicabilidad se desestima porque se trataría de una "cuestión de legalidad". MARTínez, José Ignacio, cit. (n. 40), pp. 385-387 defiende el carácter vinculante de estas sentencias "interpretativas", porque opina que la aplicación judicial de la ley sólo será constitucional "si [la ley] se interpreta conforme a lo que señale el Tribunal [en sus sentencias]”. ZAPATA, Patricio, Las sentencias atipicas en la jurisprudencia del Tribunal Constitucional chileno, en Estudios Constitucionales, 4 (2006) 2, pp. 175-187, p. 181 defiende como una consecuencia lógica de la supremacía interpretativa del Tribunal, el efecto vinculante y erga omnes de sus prevenciones o sentencias interpretativas. Avilés, Víctor Manuel, Las sentencias interpretativas del Tribunal Constitucional y los cuestionamientos o dificultades que las mismas presentan, en Revista de Derecho Público, 72 (2010), pp. 211-225 ofrece un repertorio de los problemas que presentan este tipo de sentencias de inaplicabilidad.

${ }^{45}$ Fue el caso de Silvia Peña Wasaff, a quien se le declaró inadmisible el recurso de protección después de haber obtenido la primera sentencia de inaplicabilidad del artículo 38 ter de la Ley de Isapres. "Peña Wasaff con Isapre ING Salud S.A.", Corte de Apelaciones de Santiago, 24 de septiembre de 2008, rol No 4972-2007. Confirmada por la Corte Suprema, 30 de diciembre de 2008, rol No 6482-2008. La sentencia del Tribunal Constitucional fue la rol No 976, de 26 de junio de 2008.

${ }^{46}$ Gómez, Gastón, La reforma constitucional a la jurisdicción constitucional. El nuevo Tribunal Constitucional chileno, en ZúÑIGa, Francisco (coordinador) Reforma Constitucional (Santiago, LexisNexis, 2005), pp. 651-684, p. 676 dice que la inaplicabilidad que se planteara inmediatamente después de notificada la demanda, tendría los "pies de barro" y el interesado estaría actuando "a ciegas".

${ }^{47}$ Esta posibilidad supondría una interpretación literal del artículo 92 de la LOTC. ("La sentencia que declare la inaplicabilidad sólo producirá efectos en el juicio en que se solicite").

${ }^{48}$ Aldunate, Eduardo, Jurisprudencia, cit. (n. 41), p. 12, enumera algunos casos en que el juicio de constitucionalidad a través de la inaplicabilidad es eventual necesariamente. A estas dificultades habría que añadir otra: en casación, una sentencia de 
El texto del artículo $93 \mathrm{~N}^{\circ} 6$ dice que podrá requerirse de inaplicabilidad contra un precepto legal cuya aplicación "resulte" contraria a la Constitución. Literalmente podría deducirse que no procede contra un precepto legal cuya aplicación "pueda resultar" contraria a la Constitución. Pero no ha sido esta la interpretación que ha primado: la inaplicabilidad puede interponerse aun cuando el precepto legal no haya sido aplicado por el juez. En realidad, uno debería decir que la inaplicabilidad sólo interesa mientras el precepto legal no haya sido aplicado por el juez, porque si ya fue aplicado, ¿de qué me sirve la sentencia favorable? Mas, si el precepto legal no ha sido aplicado, el Tribunal Constitucional debe dictar sentencia imaginando el sentido en que puede resultar inconstitucional.

Aldunate dice que, para decidir una inaplicabilidad, el Tribunal Constitucional tiene la difícil tarea de "proyectar la 'posible' aplicación de un precepto legal, para entrar luego a evaluar la constitucionalidad de la misma" ${ }^{49}$. En el mismo sentido Massmann, para quien el requerimiento de inaplicabilidad "está ideado para impugnar la presumible interpretación o aplicación de un precepto en el contexto de un litigio, cuando se estima que será contraria a la Constitución" 50 . Y Verdugo, que sostiene que "la inaplicabilidad tiene por objetivo revisar una aplicación judicial de la ley antes de que esta aplicación se produzca, lo que hace que el examen de constitucionalidad sea prospectivo" 51 .

Este desajuste entre la descripción del supuesto de hecho de la inaplicabilidad -que exige la aplicación de un precepto legal- y la posibilidad del juicio de inaplicabilidad -que inevitablemente recaerá sobre la eventual aplicación de un precepto legal- es lo que justificaría calificar el diseño de la inaplicabilidad como imposible ${ }^{52}$.

El carácter anticipatorio o hipotético del juicio de inconstitucionalidad, tanto en la admisibilidad como en la decisión de fondo, debilitan los efectos directos e indirectos de las sentencias de inaplicabilidad en los tribunales.

inaplicabilidad no debería tener ningún efecto, porque allí no se aplica la ley, sino que se examina cómo fue aplicada por el tribunal inferior. Aunque quizá sea esta una dificultad más teórica que práctica.

${ }^{49}$ Aldunate, Eduardo, La acción de inaplicabilidad: ¿control concreto? en La Semana Jurídica, "Edición Especial” (2010), p. 3. Esto es lo que llamó en 2007 "casación constitucional adivinatoria”: AldunATE, Eduardo, La reforma constitucional del año 2005 desde la Teoría del Derecho y la Teoría de la Constitución, en Revista de Derecho Público, 69 (2007) 1, pp. 35-44, p. 42.

${ }^{50}$ Massman, Nicolás, La admisibilidad del recurso de inaplicabilidad: a tres años de la reforma, en Ius et Praxis, 15 (2009) 1, pp. 263-293, p. 267.

${ }^{51}$ Verdugo, Sergio, Inaplicabilidad y vicios de forma. ¿Un problema resuelto? en Revista de Derecho Universidad Austral de Chile, 23 (2010) 2, pp. 83-112, p, 105.

${ }^{52}$ Este calificativo se lo oí al profesor Eduardo Aldunate. 
En otras palabras, el condicionamiento que el supuesto de hecho de la inaplicabilidad impone al juicio de constitucionalidad produce sentencias débiles $^{53}$. Esta debilidad se nota en el modo como la Corte Suprema acoge las sentencias de inaplicabilidad.

b) La práctica de la Corte Suprema. Si el Tribunal Constitucional fuera el intérprete supremo de la Constitución, sus juicios sobre la constitucionalidad de la ley serían acatados por todos los operadores jurídicos. Si la inaplicabilidad fuera un cauce idóneo de la supremacía interpretativa del Tribunal Constitucional, los tribunales de justicia obedecerían sus sentencias.

No sería suficiente para demostrar que el Tribunal Constitucional es el supremo intérprete de la Constitución, la prueba de que en muchos casos la sentencia de inaplicabilidad surte efectos cabales en la gestión pendiente. Porque no se podría descartar que en todos esos casos, los tribunales acataron la sentencia debido a que se ajustaba a su propio criterio. Como prueba sería aceptable, en cambio, que en todos los casos los tribunales obedecen la sentencia de inaplicabilidad contra su propio criterio. Pero esto no ocurre en la práctica de la Corte Suprema ${ }^{54}$.

En un fallo de 30 de noviembre de 2011, la Corte Suprema rechazó un recurso de protección, aplicando un precepto legal declarado inaplicable por el Tribunal Constitucional. En el caso se discutió la negativa de la Corporación Administrativa del Poder Judicial de pagar unos bonos de desempeño a un ministro de Corte de Apelaciones, porque el año anterior habría cumplido menos de seis meses de trabajo efectivo, que es una exigencia legal (artículo 4 de la Ley No 19.531 reformado por la Ley No 20.224). El recurrente invocó las licencias médicas que justificaban su ausencia laboral por una enfermedad catastrófica, pero la Corporación contestó diciendo que la única excepción de esta naturaleza contemplada por la ley es la de las licencias médicas por accidentes del trabajo o descansos por maternidad (artículo 4 inciso $5^{\circ}$ de la Ley No 19.531). Entonces la Corte de Apelaciones de Valparaíso, que conocía del recurso, solicitó la inaplicabilidad del artículo 4 inciso $5^{\circ}$ de la Ley $\mathrm{N}^{\circ}$ 19.531, porque sería contrario a la igualdad ante la ley y el derecho de propiedad del recurrente. El Tribunal Constitucional acogió el requerimiento en la sentencia rol No 1801 , de 12 de abril de 2011, y declaró inaplicable la parte del precepto impugnado que impedía el pago del bono de desempeño,

${ }^{53}$ Zúñiga, Francisco, Acciones, cit. (n. 26), pp. 27-28; ZúÑiga, Francisco, Acción, cit. (n. 28), p. 307.

${ }^{54}$ GómEZ, Gastón, cit. (n. 59), p. 678 vislumbró esta posibilidad: "puede que exista una tendencia de los órganos jurisdiccionales a desconocer o a sortear esos fallos de inaplicabilidad con impredecibles consecuencias". La causa de esta tendencia sería la tensión provocada por la intervención del Tribunal Constitucional en la esfera de la jurisdicción común a que inevitablemente conduce la inaplicabilidad. 
por vulnerar la igualdad ante la ley y el derecho de propiedad. La Corte de Apelaciones de Valparaíso acogió a su vez el recurso de protección, pero la sentencia fue apelada. Conociendo la apelación, la Corte Suprema se preguntó en primer lugar "si la declaración de inaplicabilidad pronunciada por el Tribunal Constitucional [...] es vinculante para el presente recurso de protección o si por el contrario tal declaración no tiene influencia en la resolución de estos autos" $"$. Y contestó que no resultaba vinculante, porque la norma declarada inaplicable fue aplicada por la recurrida antes de la sentencia del Tribunal Constitucional; es decir, la Corporación Administrativa del Poder Judicial "se encontraba obligada a obrar como lo ordena ese mandato legal" (considerando $3^{\circ}$ ). Luego, "el hecho de que con posterioridad el Tribunal Constitucional haya declarado inaplicable el precepto legal (...) no implica que tal proceder sea ilegal" (considerando $4^{\circ}$ ). Se incumple así uno de los requisitos del recurso de protección (que la acción sea ilegal), por lo que debe rechazarse.

El criterio sostenido en la sentencia "Gómez Montoya con Corporación Administrativa del Poder Judicial” torna inútil toda sentencia de inaplicabilidad, porque siempre será dictada con posterioridad a las actuaciones que motivan el juicio y el requerimiento ${ }^{56}$. Lo dijo el Ministro Haroldo Brito en su voto disidente: la sentencia de inaplicabilidad produce efecto "desde que el precepto [impugnado] entró en vigencia, porque en esta ocasión se produjo la contradicción con la Constitución; y porque, razonando desde la función de la acción de inaplicabilidad, de no ser asi, perdería eficacia toda vez que los hechos muy probablemente resultarian ser acordes con la norma por causa de la declaración siempre posterior" ${ }^{25}$.

Otro caso que se presta bien para mostrar lo inútiles que resultan las sentencias de inaplicabilidad cuando la Corte Suprema quiere, es el juicio de protección que se promovió a propósito de la obligación del turno de los abogados. Un abogado recurrió contra dos juezas del Juzgado de Familia de Osorno, por las resoluciones que dictaron designándolo abogado de turno. Alegó que la obligación de trabajar forzosa y gratuitamente era inconstitu-

55 "Gómez Montoya con Corporación Administrativa del Poder Judicial", Corte Suprema, 30 de noviembre de 2011, rol No 4518-2011, considerando $1^{\circ}$. Sentencia redactada por el ministro Pedro Pierry, con voto disidente del Ministro Haroldo Brito.

${ }^{56}$ Esta sentencia ayuda a pensar en el alcance del término "aplicación" del artículo $93 \mathrm{~N}^{\circ} 6$ : ¿se refiere sólo a la aplicación que motiva el juicio? ¿Se refiere sólo a la aplicación que se haga de la norma en el juicio? ¿Se refiere a ambos supuestos? Porque con el criterio del caso "Gómez Montoya" se enerva el efecto de la inaplicabilidad en ambos supuestos.

${ }^{57}$ Considerando $2^{\circ}$ del voto disidente. A propósito de este fallo: Verdugo, Sergio El nuevo "round" entre el TCy los Tribunales Superiores: Dificultad ineludible del modelo de cohabitación kelseniano, disponible en http://diarioconstitucional.cl/mostrararticulo.php?id=101 
cional, por contrariar las garantías $\mathrm{N}^{\circ} 2,16,20$ y 26 del artículo 19 C.Pol. La Corte de Apelaciones de Valdivia rechazó el recurso. La sentencia se apeló, y entonces se requirió de inaplicabilidad contra el artículo 595 inciso $1^{\circ} \mathrm{COT}$., que establecía la obligación gratuita del turno de los abogados. El Tribunal Constitucional acogió la inaplicabilidad y declaró inconstitucional la expresión "gratuitamente" del artículo impugnado ${ }^{58}$. Consideró que el turno de los abogados es un medio lícito pero excepcionalísimo de satisfacer la necesidad de asistencia jurídica, pero si es gratis resulta "desproporcionadamente gravoso" y, por lo tanto, contrario a la igualdad ante la ley ${ }^{59}$. Pese a esta sentencia de inaplicabilidad, la Corte Suprema rechazó el recurso de protección, porque de su lectura se desprende que lo declarado inconstitucional fue la gratuidad y no la obligación del turno. " $[E] n$ tales condiciones el recurso [...] no puede prosperar y debe ser desestimado, sin perjuicio de los demás derechos que el actor pueda hacer valer para obtener el pago de sus honorarios en el evento que el turno efectivamente sea cumplido" 60 .

Formalmente, la Corte Suprema acató la sentencia de inaplicabilidad, pero considerando las cosas desde la perspectiva de su efectividad, el acatamiento resultó insatisfactorio. Que la declaración de inconstitucionalidad del turno gratuito signifique para el interesado que debe cumplir con su obligación, "sin perjuicio de los demás derechos que [...] pueda hacer valer para obtener el pago de sus honorarios" no es el efecto que cabría esperar de las sentencias del intérprete supremo de la Constitución.

Un nuevo ejemplo que ilustra la ineficacia de las sentencias de inaplicabilidad y la consiguiente relatividad de la supremacía interpretativa del Tribunal Constitucional, lo provee la discusión sobre la constitucionalidad del artículo 38 ter de la Ley de Isapres ${ }^{61}$. Dentro del conjunto de sentencias, es paradigmática la sentencia "Fernández Bitterlich con Isapre Colmena Golden Cross", de 26 de octubre de $2009^{62}$. Se trató de un recurso de protección interpuesto contra la Isapre por el reajuste del precio base de su plan de salud y la aplicación de la tabla de factores, que significó un aumento del precio de su cotización mensual. La Corte de Apelaciones rechazó el recurso parcialmente, porque según ella la actuación de la Isapre recurrida se ajustó

${ }^{58}$ Sentencia del Tribunal Constitucional rol No 755, de 31 de marzo de 2008.

${ }^{59}$ Considerando $34^{\circ}$ y $46^{\circ}$.

60 “Sergio Toloza Rodríguez con Jueces del Juzgado de Familia de Osorno”, Corte Suprema, 24 de junio de 2008, rol No 6626-2006, considerando $5^{\circ}$ (redacción del ministro Pedro Pierry).

${ }^{61}$ Es el artículo 199 del Decreto con fuerza de ley $N^{\circ}$ 5/2005 del Ministerio de Salud.

62 "Bitterlich con Isapre Colmena Golden Cross", Corte Suprema, 26 de octubre de 2009, rol No 7779-2008. 
a las condiciones del contrato legalmente celebrado entre el cotizante y la Isapre. Se apeló la sentencia a la Corte Suprema y desde allí se requirió de inaplicabilidad contra el artículo 38 ter. El Tribunal Constitucional acogió por siete votos contra dos la inaplicabilidad, declarando inconstitucional el precepto legal impugnado por vulnerar las garantías $\mathrm{N}^{\circ} 9$ y 18 del artículo 19 C.Pol. Dada la naturaleza del contrato de salud previsional, es "constitucionalmente inaceptable el incremento de las cotizaciones en el tiempo por el solo becho del envejecimiento natural del cotizante y/o de sus beneficiarios" ${ }^{3}$. La Corte Suprema confirmó la sentencia apelada y rechazó el recurso de protección. La sentencia de inaplicabilidad no tuvo ninguna incidencia en la resolución porque, a juicio de la Corte, el artículo 38 ter no era parte de la relación contractual entre el cotizante que recurrió y la Isapre recurrida. El contrato se celebró antes de la entrada en vigencia del artículo 38 ter y, por lo tanto, la actuación de la Isapre se amparó en él y no el precepto impugnado. Para reforzar el argumento, la Corte invocó el voto en contra del Ministro Enrique Navarro en la sentencia del Tribunal Constitucional rol № 1287 : "como lo señalara el Ministro del Tribunal Constitucional [...] en su disidencia, el precepto en cuestión no resulta aplicable para la resolución del asunto sometido al conocimiento de esta Corte, pues no forma parte del estatuto jurídico que rige la relación contractual existente entre el reclamante y la Isapre" ${ }^{34}$.

De nuevo podría defenderse la corrección formal del fallo de la Corte Suprema, pero es innegable que su decisión en el caso "Bitterlich" desconoció la interpretación del Tribunal Constitucional sobre la naturaleza del contrato de salud previsional y el alza del precio de la cotización en razón de la edad del cotizante y/o beneficiario. Aquí no importa saber quién tuvo mejores argumentos para resolver el caso conforme a Derecho (si la Corte Suprema o el Tribunal Constitucional), sino destacar la inoperancia de la sentencia de inaplicabilidad en la jurisprudencia de la Corte Suprema.

Un último ejemplo sobre el débil efecto de las sentencias de inaplicabilidad no involucra a la Corte Suprema, pero es útil para ilustrar el punto. Se trata de la correcta interpretación de los artículos 186 y 230 CPP. Inicialmente, el Tribunal Constitucional estimó inaplicable el artículo 230 CPP., porque las facultades discrecionales del fiscal para formalizar afectaban el derecho de acceso a la jurisdicción de las víctimas querellantes ${ }^{65}$. Posteriormente, los requerimientos de inaplicabilidad contra el artículo 230 CPP.

\footnotetext{
${ }^{63}$ Sentencia del Tribunal Constitucional rol No 1287, de 8 de septiembre de 2009, considerando $67^{\circ}$.

${ }^{64}$ "Bitterlich con Isapre Colmena Golden Cross", considerando $11^{\circ}$. El mismo argumento en una situación equivalente, se repitió en la sentencia "Andrade Fuentes con Isapre Masvida S.A.”, Corte Suprema, 24 de septiembre de 2010, rol № 4881-2010.

${ }^{65}$ Sentencia del Tribunal Constitucional rol No 815, de 19 de agosto de 2008.
} 
fueron rechazados, porque el artículo 186 CPP., interpretado conforme a la Constitución, permitía a los querellantes forzar la formalización cuando el fiscal no lo hiciera ${ }^{66}$. Las palabras del Tribunal fueron: "el articulo $186 \mathrm{del}$ Código Procesal Penal (...) correctamente interpretado, según lo asentado por esta Magistratura en sentencias de inaplicabilidad roles $N^{\circ} 1.337$ y $N^{\circ} 1.380$, [...] permite inducir la formalización" ${ }^{37}$. No obstante, los juzgados de garantía en general no siguieron esta interpretación y mantuvieron el criterio de considerarse incompetentes para inducir la formalización cuando el fiscal no lo hacía. De este modo, las víctimas "se queda[ron] con una declaración no vinculante del Tribunal Constitucional acerca de la correcta interpretación legal"68.

c) El mal diseño institucional. Al requerir de inaplicabilidad y obtener sentencia favorable, se espera como efecto inmediato la inaplicabilidad del precepto en el juicio. El Tribunal Constitucional decide que la aplicación del precepto en cuestión produce un resultado contrario a la Constitución, y para evitar ese resultado declara su inaplicabilidad. Si los tribunales efectivamente dejaran de aplicar el precepto, pero dictaran una sentencia con la que se produjeran los resultados que el Tribunal juzgó como contrarios a la Constitución, ¿sería útil la inaplicabilidad? Como la respuesta es negativa, entonces las razones que el Tribunal Constitucional estima para declarar inaplicable una ley también deben ser tenidas en cuenta por los tribunales al momento de acatar la sentencia de inaplicabilidad ${ }^{69}$. De lo contrario, se

${ }^{66}$ Esta jurisprudencia inicialmente vacilante, se halla decantada en la sentencia del Tribunal Constitucional rol No 1341, de 15 de abril de 2010. Piedrabuena, Guillermo, Control judicial anterior a la formalización de la investigación (artículo $186 \mathrm{del}$ Código Procesal Penal), en Revista de Derecho Consejo de Defensa del Estado, 23 (2010), pp. 9-38, disponible en http://www.cde.cl/wps/wcm/connect/2c1c5b80456a3f7 89b2a9b32d05f89d2/Rev+23_5+control+judicial+anterior+a+la+formalizacio $\mathrm{n}+\mathrm{de}+\mathrm{la}+$ investigacion. pdf?MOD=AJPERES, pp. 31-37 ofrece un resumen de la jurisprudencia del Tribunal en esta materia.

${ }^{67}$ Considerando $10^{\circ}$.

${ }^{68}$ Correa, Jorge, cit. (n. 43), p. 63. Cuatro ministros disidentes consignaron que en esta materia, "el Tribunal [Constitucional] no conoce causas que demuestren que el Ministerio Público o los jueces de garantía hayan seguido en algún caso la interpretación que el Tribunal Constitucional tuvo en cuenta anteriormente para salvar la constitucionalidad del artículo 186 del Código Procesal Penal", sentencia del Tribunal Constitucional No 1489 , de 5 de octubre de 2010, considerando $5^{\circ}$.

${ }^{69}$ Carreño, Gonzalo - Jaraquemada, Jorge, cit. (n. 20), p. 409; Colombo, Juan, Las sentencias, cit. (n. 1), p. 285, dice que todas las instituciones se ven influenciadas por los fundamentos de las decisiones del Tribunal Constitucional. En el mismo sentido NúÑEZ, Manuel, cit. (n. 23), p. 134. El mismo Tribunal dijo en la sentencia del Tribunal Constitucional rol No 472, de 30 de agosto de 2006, considerando $11^{\circ}$, que "la inaplicabilidad declarada deba ser considerada por el juez llamado a resolverla, tanto 
repetiría el antiguo expediente para incumplir una orden sin desafiar a quien la dicta: "se acata, pero no se cumple".

El Tribunal Constitucional interpreta la ley en las circunstancias concretas de su aplicación y decide que sus resultados son inconstitucionales. Para que la decisión tenga el efecto de enervar esos resultados inconstitucionales, debe existir una estructura normativa que lo permita. En otras palabras, para que la inaplicabilidad sea útil es preciso, entre otras cosas, un diseño institucional adecuado. Y el diseño actual no es adecuado, por lo menos por un motivo: sus sentencias no son vinculantes para los tribunales. Esto significa que la interpretación de la Constitución hecha por el Tribunal Constitucional puede ser desconocida por los demás jueces. Luego, si la interpretación que el Tribunal Constitucional haga de la Constitución no tiene la fuerza para imponerse a los tribunales de justicia, no puede afirmarse que es el intérprete supremo de la Constitución.

Ya se dijo cómo la reforma de la Ley orgánica del Tribunal Constitucional contemplaba en su formulación original una declaración expresa del efecto vinculante de las sentencias del Tribunal Constitucional. Antes de que la reforma se aprobara, hubo quienes abogaron por esta disposición ${ }^{70}$; y después que la reforma fue aprobada, hubo quien lamentó que la disposición fuera eliminada ${ }^{71}$. Esto porque había conciencia de la necesidad de asegurar normativamente la superioridad de la interpretación que el Tribunal Constitucional hiciera de la Constitución.

No existe ninguna norma que disponga la obligatoriedad de sus sentencias para los demás órganos del Estado. Es más, el artículo 3 CC. conspira contra la posición suprema de los máximos intérpretes jurisdiccionales de la Constitución, porque restringe el efecto de sus sentencias a las partes involucradas en el conflicto ${ }^{72}$. El contenido de sus decisiones no se extiende

en lo que se refiere a los fundamentos de ésta cuanto a todo otro razonamiento que implique que la decisión del asunto no resultará contraria a la Constitución".

${ }^{70} \mathrm{CEA}$, José Luis, Efectos de la declaración de inconstitucionalidad. Dificultades y desafíos, en Actualidad Jurídica, 17 (2008), pp. 165-174, p. 170; BulnEs, Luz, cit. (n. 11), p. 56; CeA, José Luis, El proyecto, cit. (n. 1), p. 69. Verdugo, Mario, Efectos vinculantes de los precedentes del Tribunal Constitucional en la actividad de la Contraloría General de la República, en Estudios Constitucionales, 4 (2006) 1, pp. 223-231, pp. 230231 tenía reservas sobre el alcance del artículo en relación a la autonomía de la Contraloría General de la República.

${ }^{71}$ Nogueira, Humberto, La sentencia, cit. (n. 1), p. 102.

${ }^{72}$ No estoy diciendo que el artículo 3 valga sin más para las sentencias del Tribunal Constitucional, pero sí que podría ser utilizado como un argumento para afirmar el efecto relativo que tienen, como de hecho entiendo que lo fue -aunque tácitamenteen la discusión de la Ley No 20.418. La Corte Suprema ha estimado que el principio del efecto relativo de las sentencias "representa una garantía de la independencia de los 
con efecto vinculante a los casos similares que puedan darse en otras jurisdicciones o a través de otros procedimientos ${ }^{73}$. Si las sentencias no vinculan a los tribunales, es difícil imaginar motivos para que vinculen a los demás órganos del Estado. Luego, el efecto de las sentencias sería sólo persuasivo ${ }^{74}$. De allí que se haya apelado a la buena fe de los destinatarios de la sentencia para asegurar su cumplimiento ${ }^{75}$.

Puede ser conveniente comparar las siguientes palabras de José Luis Cea con la realidad que presenté en el apartado inmediatamente anterior: "Apartarse de una orden del Tribunal [Constitucional], eludirla, suspenderla, modificarla o transgredirla tiene que ser [...] motivo de investigación y sanción por los órganos políticos y jurisdiccionales competentes [...]. Si no sucede así, quiere decir que el sistema institucional se halla en crisis o está cercano a ella" ${ }^{\text {" }}$. No comparto el tono dramático de la conclusión, porque la práctica ha demostrado que existe una relación deferente entre la Corte Suprema y el Tribunal Constitucional, que mantiene a raya la posibilidad de una crisis institucional. Pero subsiste el motivo que provoca los temores de Cea: no hay ningún medio político ni jurídico para asegurar que los tribunales de justicia acaten las sentencias del Tribunal Constitucional como lo que deberían ser: expresión del máximo intérprete de la Constitución ${ }^{77}$.

La efectividad de las sentencias de inaplicabilidad está sujeta a la voluntad

jueces [...] al no quedar sometido un tribunal inferior a otra imposición vinculante que no sea el peso y la fuerza de los razonamientos contenidos en la jurisprudencia orientadora de una Corte Superior": pronunciamiento del Tribunal Pleno de la Corte Suprema, 19 de junio de 2002, rol No 1450-2002.

${ }^{73}$ En la historia del proyecto de reforma de la Ley Orgánica del Tribunal Constitucional quedó constancia de que este fue el criterio de los legisladores para negar el efecto vinculante de las sentencias del Tribunal Constitucional, excepto la declaración de inconstitucionalidad del artículo 93 No 7: "Segundo Informe de la Comisión de Constitución, Legislación y Justicia del Senado”, 15 de enero de 2007, pp. 30 y 31, Boletin 4059-07.

${ }^{74}$ Nogueira, Humberto, La sentencia, cit. (n. 1), p. 109. Cea, José Luis, Efectos, cit. (n. 83), p. 170, dice que la carencia de imperio de las sentencias del Tribunal Constitucional "presupone una disposición, constante y sin reticencias, de todos los órganos jurídicos y políticos competentes para honrar las sentencias del Tribunal [...]”.

${ }^{75}$ Fermandois, Arturo, Efecto, cit. (n. 11), p. 685 y 691.

${ }^{76} \mathrm{CEA}$, José Luis, Efectos, cit. (n. 83), p. 170.

${ }^{77}$ Hay que decir también que el propio Tribunal Constitucional contribuye a relativizar aún más el valor de sus sentencias (y con ellas, de su interpretación), cuando declara la inaplicabilidad de un precepto legal "en el entendido que" o "solo en cuanto", porque restringe el alcance de sus sentencias. Ver, por ejemplo, la sentencia del Tribunal Constitucional rol No 736, de 29 de noviembre de 2007, sentencia del Tribunal Constitucional rol No 747 , de 31 de agosto de 2007, sentencia del Tribunal Constitucional rol No 806, de 11 de diciembre de 2007, sentencia del Tribunal Constitucional 
de los tribunales de justicia ${ }^{78}$. La interpretación de la Constitución que hace el Tribunal Constitucional compite con la interpretación que hacen los tribunales de justicia. Existe una tensión entre el Tribunal Constitucional y la Corte Suprema, que se expresa, entre otras formas, en la relativa ineficacia de las sentencias de inaplicabilidad ${ }^{79}$. El mal diseño institucional que significa la ausencia de efecto vinculante de estas sentencias, deja prácticamente inoperante este aspecto de la reforma constitucional de 2005 y supone una seria objeción a la supremacía interpretativa del Tribunal Constitucional. Pero el defecto de diseño no es la causa de la tensión entre la Corte Suprema y el Tribunal Constitucional, sino que un amplificador de ella. La verdadera causa es que ambos órganos interpretan la ley y compiten por cuál interpretación debe prevalecer.

\section{La inaplicabilidad sirve para interpretar la ley.}

Jorge Correa ilustra bien la tensión que existe entre la Corte Suprema y el Tribunal Constitucional respecto de los alcances de la inaplicabilidad, y lo hace sirviéndose de los esfuerzos que el Tribunal ha hecho para delimitar su competencia frente a la de la Corte. Muestra cómo los esfuerzos del Tribunal Constitucional se orientan a establecer el ámbito de lo constitucional, que le es propio, y el ámbito de lo legal, propio de los jueces de fondo. Pero es un resultado que se consigue a duras penas, si es que se consigue. El límite entre lo legal y lo constitucional es tan esquivo, que no cuesta nada al Tribunal inmiscuirse en la esfera de la Corte Suprema, así como no cuesta nada a la Corte inmiscuirse en la esfera del Tribunal Constitucional. Concluye Correa con estas palabras: "La cuestión, en definitiva, es una de diseño institucional acerca de dónde radicar el control de la supremacía constitucional. En la especie, las opciones se mueven entre los tribunales ordinarios y el propio $\mathrm{TC}{ }^{80}$.

rol No 815, de 19 de agosto de 2008. Aldunate, Eduardo, Jurisprudencia, cit. (n. 41), p. 46 estima que estos matices tornan impreciso el efecto de las sentencias.

${ }^{78}$ Nogueira, Humberto, La sentencia, cit. (n. 1), p. 109 dice que, por carecer de imperio, las sentencias del Tribunal Constitucional sirven como criterio de interpretación a los demás órganos, "en la medida que los [...] consideren pertinentes".

${ }^{79}$ Es cierto que los casos expuestos no son habituales. Pero, aunque pudieran calificarse de "casos límite", son una prueba del diseño defectuoso de la inaplicabilidad, que hasta ahora ha sido quizá compensando por el buen entendimiento que es normal entre el Tribunal Constitucional y el Poder Judicial.

${ }^{80}$ Correa, Jorge, cit. (n. 43), p. 62. Gómez, Gastón, cit. (n. 59), pp. 670, 673, 677-679 advirtió la tensión que supondría la inaplicabilidad entre la Corte Suprema y el Tribunal Constitucional, porque la inaplicabilidad supone inevitablemente para el Tribunal Constitucional inmiscuirse en el ámbito que tradicionalmente ha correspondido al poder judicial. SAenger, Fernando, Acción de inaplicabilidad e inconstituciona- 
La conclusión de Correa mantendría el mismo valor si se sustituyera la expresión "supremacía constitucional” por "interpretación definitiva de la ley”. Porque la inaplicabilidad es un mecanismo de interpretación de la ley, y precisamente por esta razón genera tensión entre el Tribunal Constitucional y la Corte Suprema. En el fondo, la cuestión podría plantearse como quién es el intérprete final de la ley. Interpretación de la ley y control de constitucionalidad son, en la inaplicabilidad, términos conmutativos ${ }^{81}$. Y en la medida que la ley objetada por la inaplicabilidad haya sido aplicada por el juez, el juicio de constitucionalidad de la ley implica necesariamente un control de las resoluciones judiciales.

a) Un caso para ilustrar. Aunque la teoría presenta al Tribunal Constitucional como el máximo intérprete de la Constitución, y la interpretación de la ley como una tarea accesoria - si no ajena- a las de su competencia, lo cierto es que hay buenas razones para negar que lo segundo sea verdad. La principal entre éstas es la imposibilidad teórica de controlar la constitucionalidad de la ley sin interpretarla: para saber si una ley es conforme o no con la Constitución, es indispensable determinar su sentido y alcance. La inaplicabilidad supone juzgar la constitucionalidad de la ley aplicada a un caso concreto. Por esto, la determinación del sentido y alcance de la ley impugnada es una condición para decidir el punto. Con la exposición de un caso, lo dicho puede percibirse con claridad. Por esto se examinará cómo el Tribunal de hecho interpreta la ley cuando controla su constitucionalidad, con la sentencia rol 1340, de 29 de septiembre de 2009.

El caso se produjo con ocasión de la impugnación que el presidente del Juzgado de Familia de Pudahuel hizo del artículo 206 CC. Este artículo dice: "Si el hijo es póstumo, o si alguno de los padres fallece dentro de los ciento ochenta dias siguientes al parto, la acción [de reclamación de la filiación] podrá dirigirse en contra de los herederos del padre o de la madre fallecidos, dentro del plazo de tres años, contados desde su muerte o, si el hijo es incapaz, desde que éste haya alcanzado la plena capacidad". El motivo que tuvo el juez para

lidad. Facultades del nuevo Tribunal Constitucional. Algunos casos jurisprudenciales, en Estudios Constitucionales, 5 (2007) 1, pp. 305-348, p. 282 a su modo también identifica el acercamiento de las competencias del Tribunal Constitucional y la Corte Suprema al decir que la inaplicabilidad "es una especie de instancia [...] que se asemeja a las competencias que en materia civil y penal (sistema antiguo), otorga la ley a las Cortes de Apelaciones [...] o incluso a la Corte Suprema en el caso del recurso de amparo y protección”.

${ }^{81}$ GómEZ, Gastón, cit. (n. 59), pp. 678 y 679: “para llevar a cabo el proceso de control [de constitucionalidad de la ley, el Tribunal Constitucional] debe interpretar la Constitución para determinar su sentido y también debe interpretar la ley. [...] La labor de interpretar la Constitución, de cara al control constitucional, presupone juzgar la ley y las valoraciones que el legislador adopta normativamente". 
requerir de inaplicabilidad por inconstitucionalidad contra este precepto legal es que "impediría al presunto hijo de un padre que fallece con posterioridad a los 180 días siguientes al parto, demandar el reconocimiento de su filiación en contra de los herederos de ese presunto padre fallecido", lo cual sería contrario al derecho fundamental a la identidad y a la igualdad ante la ley, "ya que -a su entender-establecería una discriminación que no resistiría ningún test de racionalidad o proporcionalidad, entre los presuntos hijos de padres fallecidos para demandar su filiación, considerando sólo el momento del fallecimiento del presunto padre".

En el considerando $15^{\circ}$ el Tribunal Constitucional definió la cuestión que debía decidir: "si la aplicación de la regla contemplada en el artículo 206 del Código Civil podía resultar contraria al artículo $5^{\circ}$, inciso segundo, de la Constitución, permitiendo que los órganos del Estado - el legisladory, eventualmente, el sentenciador de fondo-incumplan su deber de respetar y promover el derecho a la identidad personal". En el considerando siguiente el Tribunal Constitucional advirtió de los dos criterios enfrentados en la doctrina acerca de la inteligencia de esta norma. Estos criterios reflejaban los distintos bienes que la norma trataba de equilibrar: de una parte la bondad de conocer la identidad de sus padres y participar en la herencia como hijo y, de otra parte, la bondad de preservar la armonía familiar, evitando alterar la distribución de los bienes de la herencia y la exhumación del cadáver en cualquier tiempo. Tanto unos bienes como otros son protegidos por la Constitución.

El artículo 206 CC. admitía dos interpretaciones, incompatibles entre sí como incompatibles eran los bienes que cada una prefería: ¿por cuál debía inclinarse el Tribunal Constitucional? Independientemente de la decisión que adoptare, es evidente que entre el conocimiento del asunto y el resultado de la sentencia, media un proceso de interpretación del artículo 206 CC. Cualquiera sea la interpretación por la que opte, es innegable que se habrá pronunciado sobre su sentido y alcance. ¿Acaso no es esta una típica hipótesis de las "cuestiones de legalidad"?

El voto en contra suscrito por tres ministros reclamó que este era un caso ajeno a la competencia del Tribunal Constitucional, por ser una "cuestión de legalidad": "No le corresponde a esta Magistratura sustituir al juez ordinario definiendo una interpretación legal correcta. Una intervención en ese sentido lo convierte en un juez de casación, o sea, de guardián de la correcta aplicación de la ley"82. Que el voto de mayoría interpretó la ley es algo que no puede ser puesto en duda.

Una prueba de la labor interpretativa de la ley que hizo el Tribunal Constitucional para decidir este caso es el considerando $24^{\circ}$ de la sentencia: "una

\footnotetext{
${ }^{82}$ Considerando $5^{\circ}$ del voto en contra.
} 
interpretación armónica del sistema de reconocimiento de la filiación existente en Chile permite concluir que los herederos de la persona cuya paternidad o maternidad se reclama pueden quedar salvaguardados"83. En definitiva, estimó el Tribunal Constitucional que no era aceptable una interpretación del artículo 206 CC. que resultara contraria al derecho a la identidad y a la igualdad ante la ley, y declaró inaplicable por inconstitucionalidad el precepto legal.

Si en este caso se trataba de decidir acerca de la correcta interpretación del artículo 206 CC., ¿ por qué el Tribunal Constitucional no declaró inadmisible el requerimiento de inaplicabilidad? ¿Acaso la interpretación de la ley no es el caso típico de una "cuestión de legalidad"? La valoración de esta sentencia a la luz de la jurisprudencia del propio Tribunal Constitucional en materia de admisibilidad es difícil, porque hay razones para sostener que se aparta del criterio dominante y razones para sostener que lo confirma. En efecto, es repetida la fórmula según la cual "no es función de esta jurisdicción constitucional 'aclarar el sentido que tienen determinados preceptos legales', dado que esto último importa 'una cuestión de legalidad cuya resolución es propia de los jueces de fondo ${ }^{m 84}$. En este sentido, la sentencia rol No 1340 sería contraria a la jurisprudencia. Pero también el Tribunal Constitucional ha dicho que "lo que debe resolverse en [la inaplicabilidad] es si las disposiciones legales en cuestión, correctamente interpretadas y aplicadas en el caso concreto que las motiva, vulneran o no las normas, principios y valores constitucionales, que señala la requirente, materia que ciertamente es de competencia de este Tribunal Constitucional" 85 . En este sentido, la sentencia estaría dentro de la línea fijada por la jurisprudencia, puesto que es preciso interpretar correctamente el precepto legal antes de decidir su inconstitucionalidad en el caso concreto.

La ambigüedad de la posición del Tribunal Constitucional respecto del alcance de su competencia provoca más de una crítica en la doctrina. Por ejemplo, Aldunate critica que en la sentencia rol 1010, el Tribunal haya declarado inadmisible el requerimiento contra los artículos de un decreto con fuerza de ley calificándolo como carente de fundamento razonable, porque el conflicto consistía en determinar la naturaleza pública o privada de un camino. Si de la aplicación de los preceptos impugnados dependía el reconocimiento de derechos constitucionales del requirente, entonces

\footnotetext{
${ }^{83}$ Considerando $24^{\circ}$.

${ }^{84}$ Sentencia del Tribunal Constitucional rol No 1220 , de 16 de septiembre de 2008, considerando $7^{\circ}$. Las citas internas corresponden a la sentencia del Tribunal Constitucional rol No 522, de 16 de agosto de 2006.

${ }^{85}$ Sentencia del Tribunal Constitucional rol No 1295, de 6 de octubre de 2009, considerando $38^{\circ}$.
} 
obviamente el conflicto tenía un carácter constitucional ${ }^{86}$. Pero esta crítica es extensible a todos los casos en que rehúsa conocer una inaplicabilidad, justificándose en la naturaleza meramente legal del conflicto, porque equé conflicto legal no tiene incidencia constitucional $?^{87}$. En buenas cuentas, la decisión sobre la constitucionalidad de un precepto legal impugnado a través de la inaplicabilidad, implica necesariamente la interpretación del mismo, porque no es posible saber si se conforma o no con la Constitución si no se conoce su sentido y alcance.

b) Juzgar la aplicación del precepto implica interpretar. Para aplicar la ley hay que interpretarla. La interpretación de la ley es una etapa del proceso de su aplicación. De aquí que juzgar la aplicación de la ley implique un juicio al sentido en que fue interpretada. Desde el momento que la inaplicabilidad consiste en examinar, a la luz de la Constitución, el resultado de la aplicación de un precepto legal, se convierte en una oportunidad para examinar la forma como el precepto legal fue interpretado por quien lo aplicó. La interpretación judicial de la ley es uno de los factores que el Tribunal Constitucional toma en consideración al momento de decidir una inaplicabilidad, porque la aplicación del precepto legal es inseparable de su interpretación.

La inaplicabilidad es un mecanismo que no excluye el control de la aplicación judicial de la ley. Así lo piensa Fermandois, para quien "el actual artículo $93 \mathrm{~N}^{\circ} 6$ de la Carta Máxima faculta al Tribunal Constitucional para apreciar, evaluar y enjuiciar la razonabilidad o arbitrariedad con la que la norma legal ha sido aplicada al caso concreto" ${ }^{\text {}}$. En el mismo sentido, Martínez: cuando

${ }^{86}$ Aldunate, Eduardo, Jurisprudencia, cit. (n. 41), p. 16; Martínez, José Ignacio, cit. (n. 40), p. 395 critica la sentencia rol No 810 en un sentido parecido, pero asumiendo en su crítica que hay problemas de mera interpretación de ley (o sea, sin incidencia constitucional), con lo cual no estoy de acuerdo.

${ }^{87}$ Por esta razón creo que la doctrina de las cuestiones de legalidad no satisface el estándar de racionalidad que cabría esperar de los criterios para decidir cuáles requerimientos se admiten y cuáles no. Cuestión distinta es la necesidad práctica de reducir el número de requerimientos a un número que el Tribunal pueda efectivamente conocer.

${ }^{88}$ Fermandois, Arturo, Inaplicabilidad y control concreto del Tribunal Constitucional: enjuiciando la arbitrariedad en la aplicación de la ley, en Actualidad Jurídica, 9 (2008) 17, pp. 175-192, p. 177. Más adelante se pregunta si apreciar la arbitrariedad en la aplicación de la ley significa arrogarse atribuciones propias de la justicia ordinaria, superponerse a los jueces de fondo en sus funciones (p. 190). Responde que no, aunque no encontré una razón en la respuesta que ofrece: el Tribunal Constitucional no revisa el mérito, "pero eso no significa que toda la justicia constitucional deba basarse en abstracciones puras, ideales, incorporales, descontextualizadas. Si así fuere, no tendría sentido el nuevo artículo 93 número 6 de la Carta Fundamental” (p. 190). Me parece que hay aquí una petición de principio. 
el precepto que se impugna ha sido aplicado por una sentencia judicial, "la cuestión de inaplicabilidad se transforma en un mecanismo de control de la interpretación/aplicación de una norma legal en un caso concreto" ${ }^{99}$. Y Núñez afirma, comentando la sentencia rol 707, que "la inaplicabilidad, en su nueva versión, es un instrumento [...] de control de la aplicación judicial del Derecho (...); un formidable instrumento de control de la aplicación judicial de la leyes" $"$.

Jorge Correa admite la dificultad de precisar si el efecto contrario a la Constitución lo produce una determinada interpretación legal o una decisión judicial que lo aplica91. Y la razón de esta dificultad "se deriva de que precisamente las normas sólo pueden producir un efecto en los casos a través de los jueces. El efecto contrario a la Carta en un caso no lo puede producir la norma sino a través del juez que la aplica" ${ }^{92}$. Pero luego el mismo Correa reprocha que se infiera de esto que la inaplicabilidad es un medio de impugnación de resoluciones judicial. Ofrece como explicación lo siguiente: “decenas de requerimientos de inaplicabilidad han sido rechazados o declarados inadmisibles precisamente por impugnar la constitucionalidad de lo resuelto por los jueces de la instancia y no preceptos legales"93. Esta explicación no es satisfactoria, porque el número de sentencias por sí solo no explica nada. No niego la existencia de esas sentencias, pero niego que ellas demuestren lo que Correa pretende. Si realmente el enjuiciamiento constitucional del precepto legal no puede separarse de su aplicación judicial, como antes afirmó, ¿cómo puede ser que la impugnación de un precepto se separe de la impugnación de la resolución que lo aplica? ${ }^{94}$.

${ }^{89}$ Martínez, José Ignacio, cit. (n. 40), p. 383.

${ }^{90}$ NúÑEz, Manuel, cit. (n. 23), p. 159. Además de los citados antes, Aldunate, Eduardo, Jurisprudencia, cit. (n. 41), p. 18; HormazÁbal, Hernán, cit. (n. 34), p. 18; Gómez, Gastón, cit. (n. 59), p. 669; PicA, Rodrigo, El carácter concreto del control de inaplicabilidad de la ley en el Derecho chileno, en Revista de Derecho Universidad Católica del Norte, 16 (2009) 2, pp. 101-136, p.122. Habría que aclarar la posición de Zúñiga, Francisco, Acciones, cit. (n. 26), pp. 19 y 29, porque entiendo que hay una contradicción entre afirmar, por una parte, que la inaplicabilidad no es la vía para impugnar resoluciones judiciales y, por otra, que el Tribunal Constitucional es super casatorio.

${ }^{91}$ Correa, Jorge, cit. (n. 43), p. 14.

${ }^{92}$ Correa, Jorge, cit. (n. 43), pp. 58-59. El argumento está desarrollado en la disidencia del mismo autor, en la sentencia del Tribunal Constitucional rol No 810 , de 24 de enero de 2008, especialmente el considerando $3^{\circ}$.

${ }^{93}$ Correa, Jorge, cit. (n. 43), p. 58.

${ }^{94}$ Es tan sutil la diferencia entre impugnar el precepto e impugnar la resolución que lo aplica, que Correa admite que a veces puede "radicar únicamente en la manera en que la acción es presentada”, CorREA, Jorge, cit. (n. 43), p. 16. 
La inaplicabilidad no puede decidirse sin interpretar la ley ${ }^{95}$. Esto significa que la supremacía constitucional no puede garantizarse sin interpretar la ley. Luego, el guardián de la supremacía constitucional debería ser el intérprete supremo de la ley. Pero el mismo Tribunal Constitucional, y detrás de él parte importante de la doctrina nacional, insiste en que a través de la inaplicabilidad no le compete interpretar la ley. Y aunque afirma esto con insistencia, de hecho la interpreta. Se produce entonces una confusión que resulta perjudicial en varios aspectos, pero en ninguno tanto como en la mala posición en que queda el Tribunal Constitucional para defender su función de intérprete supremo de la Constitución.

\section{El Tribunal Constitucional No ES El intérprete SUPREMO DE LA CONSTITUCIÓN}

Si la inaplicabilidad no es un cauce idóneo para la supremacía interpretativa del Tribunal Constitucional, entonces no puede afirmarse que el Tribunal sea el intérprete supremo de la Constitución simpliciter. Que a través de la inaplicabilidad el Tribunal Constitucional no interprete definitivamente la Constitución, no significa que no lo haga en absoluto: son muchas sus atribuciones, y de alguna de ellas podría quizá predicarse. Pero soy escéptico respecto de esta posibilidad por dos motivos. El primero de ellos es que la ley y la Constitución son dos elementos inseparables en el control de constitucionalidad. El segundo de ellos es la imposibilidad de una interpretación definitiva de la Constitución en nuestro Derecho.

\section{La ley y la Constitución no se pueden separar.}

Ya se dijo que la separación entre la ley y la Constitución era uno de los presupuestos para afirmar la idoneidad de la inaplicabilidad como cauce de la supremacía interpretativa del Tribunal Constitucional. Pero, más en general, es un presupuesto necesario para afirmar el control de constitucionalidad de la ley vigente sin alterar los ámbitos de competencia del poder judicial. Sólo en la medida en que el control de constitucionalidad y la interpretación de la ley puedan separarse, es posible postular la existencia de una competencia específica del Tribunal Constitucional distinta e independiente de la del poder judicial.

Sin duda que la ley y la Constitución se pueden distinguir en varios aspec-

${ }^{95}$ Rodríguez, Pablo, Constitucionalización del derecho, en Actualidad Jurídica, 22 (2010), pp. 9-20, pp. 11-13 critica la inaplicabilidad, porque extiende el ámbito de competencia del Tribunal Constitucional "pasando por encima de lo que constituye la esencia del ejercicio de la jurisdicción de los tribunales ordinarios y especiales”. SKOKNIC, Ivo, cit. (n. 29) en el mismo sentido. 
tos, pero esto no significa que se puedan manipular siempre o en cualquier sentido como realidades separadas. Tratándose del control de constitucionalidad de la ley vigente, Constitución y ley son inseparables, y la jurisprudencia de la inaplicabilidad lo muestra bien ${ }^{96}$.

Cuando digo que Constitución y ley son inseparables, quiero decir que la operación de controlar la constitucionalidad de la ley vigente sólo puede realizarse en una mutua oposición de sus textos (constitucional y legal), con el fin de precisar el sentido y alcance de la ley y de la Constitución. En el momento de enjuiciar la constitucionalidad de una ley, el juez va conociendo los posibles significados de la ley y de la Constitución, en una sucesión de cotejos entre ambas normas que van como iluminándose recíprocamente hasta que se adopta una decisión. Un pronunciamiento sobre la constitucionalidad de la ley es un pronunciamiento sobre el sentido y alcance de la ley tanto como de la Constitución. Creer que el control de constitucionalidad significa sólo determinar el sentido de la Constitución es un error ${ }^{97}$.

Las dificultades del Tribunal Constitucional para delimitar los ámbitos de lo legal y lo constitucional se originan en el afán por realizar un imposible. Por muy grande que sea la deferencia que quiera guardar con el poder judicial, cada vez que decida sobre la constitucionalidad de la ley, decidirá sobre el sentido de la ley. Esto explica las tensiones entre ambos órganos, pero sobre todo explica que el Tribunal Constitucional no puede ser el intérprete supremo de la Constitución sin ser el intérprete supremo de la ley. Zúñiga habla de monopolio jurisdiccional: el contencioso constitucional es del Tribunal Constitucional y el contencioso civil y penal del Poder Judicial ${ }^{98}$. Si de verdad esto fuera así (si de verdad, esto fuera posible), el intérprete supremo de la ley

${ }^{96}$ La jurisprudencia del control de constitucionalidad de los decretos supremos también lo prueba: Silva, Luis Alejandro, El control de constitucionalidad de los actos administrativos legales (Santiago, LegalPublishing, 2009), pp. 157-179; SILVA, Luis Alejandro, El control de legalidad del Tribunal Constitucional: dice pero no hace. Comentario a la sentencia del Tribunal Constitucional Transantiago II, rol 1.153, de 30 de septiembre de 2008, en Ius et Praxis, 15(2009) 2, pp. 319-330. El Ministro Fernández Baeza criticó en una disidencia el presupuesto de varias disposiciones de la nueva LOTC. Y este presupuesto fue "una identificación excluyente entre Constitución y ley [...], presentándose asi una visión de la Constitución restringida a su texto y al sentido literal de sus preceptos", sentencia del Tribunal Constitucional rol № 1288, de 25 de agosto de 2009 , considerando $7^{\circ}$. Lo criticó porque esta nítida separación entre ley y Constitución empobrece el concepto de Constitución.

${ }^{97}$ HormazÁBAL, Hernán, cit. (n. 34), p. 53: "Cuando el TC somete a un juicio de compatibilidad constitucional [...] a una determinada línea interpretativa de una ley vigente, está efectuando [...], sobre todo, [...] un procedimiento de interpretación de la ley".

${ }^{98}$ ZúNíiga, Francisco, Control de constitucionalidad y casación, en Anuario Iberoamericano de Justicia Constitucional, 10 (2006), pp. 335-380, pp. 366 y 377. 
sería el supremo intérprete de la Constitución, porque si otro poder pudiera enmendar la interpretación judicial de la ley en nombre de la Constitución, entonces el judicial no sería el supremo intérprete de la ley.

\section{No es posible una interpretación final.}

Cuando se habla de interpretación suprema o definitiva de la Constitución, se sobreentiende que el adjetivo "suprema" o "definitiva" está usado en sentido relativo. Porque en este mundo temporal, ninguna interpretación normativa puede pretender escapar de la provisionalidad; nada en el Derecho es definitivo. Pero dentro de las coordenadas temporales, sí puede afirmarse que hay una interpretación definitiva o suprema de la Constitución, en comparación con el alcance o duración de otras interpretaciones. Hay interpretaciones de la Constitución más o menos provisionales, podría decirse. Por esto, para discutir si es posible una interpretación definitiva de la Constitución en Chile, es preciso señalar los términos de la comparación: ¿qué se entenderá por definitiva y qué no?

Por definitiva entiendo la interpretación de la Constitución que vincula a todos los poderes del Estado - principalmente a los jueces- y que sólo puede ser modificada por el mismo intérprete. La vinculación de la interpretación definitiva no se agota en el cumplimiento de lo dispositivo de la decisión, sino que alcanza el significado de la Constitución que se tuvo en cuenta para apoyar la decisión. Podrían señalarse como ejemplos de intérpretes vinculantes de la Constitución en el sentido anotado, el caso de la Corte Suprema de los Estados Unidos ${ }^{99}$ y el Tribunal Constitucional español ${ }^{100}$. En Chile, no hay ningún órgano del Estado que interprete la Constitución según estas características. Y en el caso particular del Tribunal Constitucional, esta negación se apoya en razones de distinta naturaleza. Algunas de ellas las he calificado como contingentes, porque podrían cambiar; las otras como absolutas, porque entiendo que no pueden cambiar.

a) Razones contingentes. En este conjunto habría que considerar algunas de las razones que ya se han dado. A saber, el diseño de la inaplicabilidad (la cuestión de la oportunidad) y el carácter no vinculante de las sentencias de inaplicabilidad. Además, habría que añadir la propia jurisprudencia del Tribunal Constitucional, que por distintas vías debilita el alcance de sus sentencias. Como ejemplos de estas sentencias pueden citarse las que declaran la inconstitucionalidad de un precepto "en el entendido que", o las que rechazan el requerimiento por versar sobre "cuestiones de legalidad" o la

${ }^{99}$ Ver la sentencia de la propia Corte Suprema “Cooper v. Aaron” 358 U.S. 1 (1958).

${ }^{100}$ Ver el artículo 5.1 de la Ley Orgánica 6/1985, de 1 de julio, del Poder Judicial. 
sentencia rol No 1254 , de 29 de julio de 2009, que se desentendió del efecto práctico de la inaplicabilidad. Esta última sentencia declaró inconstitucional la expresión "gratuitamente" del artículo 595 COT. En el considerando $92^{\circ}$ respondió al reclamo sobre el modo como la Corte Suprema interpretó la sentencia de inaplicabilidad rol No 755 , porque habría agravado la situación del particular al imponerle una nueva carga pública, que era demandar al Fisco para el pago de los honorarios debidos por el turno. Dijo el Tribunal Constitucional que no le correspondía "hacerse cargo de las interpretaciones de las disposiciones subsistentes, como consecuencia de la declaración previa de inaplicabilidad por inconstitucionalidad de un determinado precepto legal", porque "los jueces de la instancia o la Corte Suprema, en su caso, son soberanos para determinar la debida interpretación de las disposiciones legales".

Otro argumento interesante dentro de este conjunto de motivos contingentes, es la posición adoptada por el Tribunal Constitucional respecto del alcance de sus sentencias de inconstitucionalidad. El ejemplo más claro es la respuesta que el Tribunal dio a la Corte Suprema cuando ella consultó sobre el camino a seguir con las causas pendientes, después de haber declarado inconstitucional el artículo 116 C.Trib.: "la sentencia de inconstitucionalidad [...] no produce, nipuede producir, ningún efecto respecto de la facultad privativa que tiene vuestra Excelencia para resolver, en ejercicio de su competencia, la causa sub lite, puesto que la potestad emanada de nuestra jurisdicción constitucional se agota en el caso concreto, con la decisión derogatoria expresada en dicha sentencia"101.

En los párrafos anteriores se han expuesto someramente los motivos para afirmar que el Tribunal Constitucional no puede ser calificado como el intérprete final de la Constitución. Pero estos motivos podrían dejar de existir. Por ejemplo, si se definiera que el Tribunal Constitucional es parte del poder judicial, jerárquicamente superior a la Corte Suprema y sus sentencias vinculantes para todos los jueces; o si se estableciera que el requerimiento de inaplicabilidad sólo puede interponerse contra una sentencia definitiva de última instancia o de casación; o, en fin, si el propio Tribunal Constitucional volviera sobre sus pasos con una afirmación más decidida sobre el efecto de sus sentencias. Pero aunque todo esto sucediera, subsistirían motivos para negar la posibilidad de un Tribunal Constitucional que interpretara definitivamente la Constitución. Estos son los motivos que he calificado como absolutos.

b) Razones absolutas. Hay razones para negar la posibilidad de una interpretación definitiva de la Constitución, que no dependen de la contingencia. Estas razones impiden afirmar que el Tribunal Constitucional sea

${ }^{101}$ Resolución rol No 793, 17 de julio de 2007, considerando $4^{\circ}$. 
el intérprete supremo de la Constitución, lo mismo que impiden afirmarlo de cualquier otro órgano. En el fondo, la Constitución no admite una interpretación definitiva ${ }^{102}$.

La imposibilidad de interpretar definitivamente la Constitución puede explicarse por dos vías diferentes que tienen una raíz común. La primera es la naturaleza de la Constitución y la segunda es la dinámica institucional que se da entre los órganos que la aplican.

Es usual que se afirme del Tribunal Constitucional la condición de intérprete supremo de la Constitución, asumiendo que la Constitución es una norma jurídica. Como se dijo más arriba, la matriz de este argumento está en la sentencia "Marbury v. Madison". Pero la Constitución no solo es norma jurídica, sino también un pacto político. Pretender explicar satisfactoriamente la naturaleza de la Constitución señalando solo su dimensión jurídica es un error; será siempre una explicación parcial. Lo mismo podría decirse del intento por explicar la Constitución solo desde su dimensión política, porque la Constitución no es solo un pacto político. Por esto es que tampoco podría sostenerse que el intérprete definitivo de la Constitución deba ser un órgano político. Ni puede pretenderse una interpretación definitiva de la Constitución de naturaleza jurídica ni de naturaleza política, porque ninguna sería definitiva al no ser la Constitución ni completamente jurídica ni completamente política ${ }^{103}$.

Una de las razones que se invoca para defender una interpretación definitiva de la Constitución, es la necesidad de cerrar el debate sobre el significado polémico de la Constitución. Si no hay una interpretación definitiva de la Constitución, se producirá una incertidumbre constante entre los jueces y, en general, en los poderes del Estado acerca de su significado ${ }^{104}$. Es necesario, o al menos conveniente, garantizar una interpretación uniforme de la Constitución $^{105}$. Típicamente se atribuye esta función de clausurar el debate

${ }^{102}$ Me doy cuenta de la ambigüedad de esta afirmación, porque antes reconocí que en términos relativos sí hay una interpretación definitiva. La verdad es que, con esta afirmación, voy más allá del caso chileno y discuto la posibilidad de una interpretación definitiva incluso en aquellos casos, como el norteamericano y el español, donde se afirma que existe. En cualquier caso, no estoy diciendo nada nuevo, porque en los Estados Unidos, por lo menos, hace tiempo que se dijo.

${ }^{103}$ El Ministro Fernández Baeza afirmó en su disidencia en la sentencia del Tribunal Constitucional No 1288 , de 25 de agosto de 2009, considerando $12^{\circ}$, que: "En la Constitución todo es jurídico y todo es politico simultáneamente”. Pero lo afirmó para explicar la potencialidad del Tribunal Constitucional para ir más allá de su auto-inhibición. En cambio, aquí la doble naturaleza de la Constitución significa un límite a la interpretación que el Tribunal hace de la norma constitucional.

${ }^{104}$ Zapata, Patricio, Justicia, cit. (n. 9), p. 365.

${ }^{105}$ Aldunate, Eduardo, Jurisprudencia, cit. (n. 41), p. 61. CorreA, Jorge, cit. (n. 
al Tribunal Constitucional ${ }^{106}$, aunque se ha propuesto que se atribuya a un órgano político ${ }^{107}$. Este punto puede discutirse en varios niveles: puede discutirse si es necesario que haya un cierre del debate sobre el significado de la Constitución, también si es conveniente que haya un tal cierre; puede discutirse quién debe ser o conviene que sea el órgano que tenga la última palabra y, por último, puede discutirse si es posible cerrar el debate sobre el significado de la Constitución. Aquí se discute esta última opción.

Precisamente porque la Constitución tiene una naturaleza jurídica y una política, no es posible afirmar su interpretación definitiva, desde la perspectiva de los distintos órganos que deben aplicarla. Porque la Constitución es aplicada por órganos jurisdiccionales y políticos, con criterios y procedimientos consistentes con la finalidad del órgano. Si todos están igualmente obligados por los preceptos de la Constitución, ¿por qué habrían unos de sujetarse definitivamente a la interpretación de un único órgano, sea político o jurisdiccional? Esta posibilidad es inimaginable en un Estado donde los distintos poderes están equilibrados en una estructura más o menos compleja de pesos y contrapesos. Postular la interpretación definitiva de la Constitución es incompatible con postular la separación de los poderes y el mutuo equilibrio ${ }^{108}$.

43), p. 69 dice que no habría Constitución que defender "si no tuviera un significado común y razonablemente constante". Y el Tribunal Constitucional "juega un papel central" en el desarrollo de su significado. La pregunta aquí es si la posición "central" significa lo mismo que "suprema".

${ }^{106}$ Nogueira, Humberto, La sentencia, cit. (n. 1), p 101; Zapata, Patricio, Justicia, cit. (n. 9), p. 365; Соlомво, Juan, Las sentencias, cit. (n. 1), p. 287; Nogueira, Humberto, El control, cit. (n. 14), p. 17.

${ }^{107}$ Atria, Fernando, cit. (n. 3), pp. 376-377. También puede entenderse que el Tribunal Constitucional es, de hecho, un órgano político o "tercera cámara": MACClure, Lucas, Tribunal Constitucional y los derechos: La discusión pendiente, en SiERRA, Lucas - MAC-Clure, Lucas, Frente a las mayorias. Leyes supramayoritarias y Tribunal Constitucional en Chile (s.e., Santiago, 2011), pp. 169-275.

${ }^{108}$ FUNDACión, cit. (n. 28), p. 10 entiende justo lo contrario a raíz de la dictación de la ley 20.418, que habría cuestionado la sentencia rol 707. Fernández, Miguel Ángel, cit. (n. 1), p. 142 expone un argumento distinto, pero que llega a una conclusión casi igual. Este argumento se basa en una comprensión más radical -si así puede decirse- del principio de supremacía constitucional. De acuerdo con esta comprensión, las decisiones del máximo intérprete de la Constitución no sustituyen la obediencia que todos deben directamente a la Constitución. La obligación de respetar la Constitución no queda satisfecha con el acatamiento de las sentencias del Tribunal Constitucional (o quien fuera el garante último de la Constitución): “... el constitucionalismo [...] hace inconcebible la concentración de la definición constitucional [...] en un sólo órgano [...] aunque se lo dote del rol de garante máximo de la Constitución [...] Por ello, todos los jueces siguen obligados a respetar la Constitución y no pueden eludir ese deber bási- 
Hace más de una década, Fernando Atria defendió la necesidad de un intérprete final de la Constitución, aceptando que el titular carecería de todo control porque esto (un poder sin control) no es algo contrario a los principios del constitucionalismo. "Alguien o algo tiene que tener autoridad y potestad para declarar qué dice la Constitución, para declarar si una ley en particular es o no inconstitucional" ${ }^{109}$. Aparte de que no encontré en su discurso ninguna razón para justificar la necesidad de un intérprete final, interpretar definitivamente la Constitución y declarar si una ley en particular es o no inconstitucional son dos cosas distintas. Se puede afirmar la necesidad de un órgano que juzgue la conformidad de la ley con la Constitución, sin concluir que lo que diga "valdrá como declaración del contenido de la Constitución aun cuando esté equivocado" 110 , es decir, sin que nadie pueda apartarse de esa declaración. Porque juzgar la constitucionalidad de la ley no es una operación que agote el significado de la Constitución.

Las razones que califiqué de absolutas pueden ser con razón objetadas de relativas. El punto no es importante si se trata sólo de una cuestión de nombres. Lo que se quiso destacar en este apartado final es que existen motivos para negar la posibilidad de una interpretación definitiva que son intrínsecos al marco conceptual en que se esta interpretación se propone.

\section{CONCLUSIÓN}

Hay buenas razones para dudar seriamente de la posición del Tribunal Constitucional como intérprete final de la Constitución. Varias de estas razones descansan en el diseño y funcionamiento de la inaplicabilidad. Aunque pudiera incluso dudarse acerca de la posibilidad de una interpretación definitiva de la Constitución, lo cierto es que la inaplicabilidad está presentando una versión inconvenientemente débil del Tribunal Constitucional y su interpretación de la Constitución. Si no quiere exponerse a este órgano a situaciones futuras cada vez más incómodas, es preciso corregir el diseño de la inaplicabilidad. Pero esta corrección debe tener presente que la ley y la Constitución no pueden aplicarse separadamente cuando se juzga la constitucionalidad de la ley. El máximo intérprete de la Constitución (o lo que más se le acerque) será inevitablemente el máximo intérprete de la ley.

co, amparándose en la existencia de un garante máximo de la supremacía constitucional". Admito que una concepción "radical" de la supremacía constitucional se traduzca en un control difuso de constitucionalidad, pero no parece coherente -ni posible- que subsistan juntos un sistema difuso de control y un "garante máximo de la Constitución”.

${ }^{109}$ Atria, Fernando, cit. (n. 3), p. 377.

${ }^{110}$ Atria, Fernando, cit. (n. 3), p. 377. 
En cualquier caso, las expectativas que una interpretación definitiva de la Constitución puedan generar deben ser moderadas por la dinámica propia de un Estado en que los poderes actúan separada y coordinadamente. La Constitución no se deja interpretar definitivamente, porque su naturaleza jurídica y política no lo permite.

\section{BiBLIOGRAFÍA}

Aldunate, Eduardo, La reforma constitucional del año 2005 desde la Teoría del Derecho y la Teoria de la Constitución, en Revista de Derecho Público, 69 (2007) I, pp. 35-44;

Aldunate, Eduardo, Jurisprudencia constitucional 2006-2008. Estudio selectivo (Santiago, LegalPublishing, 2009);

Aldunate, Eduardo, La fuerza normativa de la Constitución y el sistema de fuentes del Derecho, en Revista de Derecho de la Pontificia Universidad Católica de Valparaiso, XXXII (2009), pp. 443-484;

Aldunate, Eduardo, La acción de inaplicabilidad: ¿control concreto?, en La Semana Jurídica, Edición Especial (2010), p. 3;

Atria, Fernando, Revisión judicial: el sindrome de la víctima insatisfecha, en Estudios Públicos, 79 (2000), pp. 347-402;

Avilés, Víctor Manuel, Las sentencias interpretativas del Tribunal Constitucional y los cuestionamientos o dificultades que las mismas presentan, en Revista de Derecho Público, 72 (2010), pp. 211-225;

AA.VV., Sentencia sobre inconstitucionalidad del Decreto Supremo $N^{\circ} 48$ del Ministerio de Salud en la parte que autoriza la distribución de la "pildora del día después" en el sistema público de salud (Tribunal Constitucional), en Revista de Derecho de la Universidad Austral de Chile, 21 (2008) 1, pp. 155-170;

Bronfman, Alan, El carácter privado del proceso de inaplicabilidad por inconstitucionalidad, en Revista de Derecho de la Pontificia Universidad Católica de Valparaiso, XXXVII (2011), pp. 243-274;

Bulnes, Luz, Efectos de las sentencias de la jurisdicción constitucional en la judicatura ordinaria, en Estudios Constitucionales, 3 (2005) 1, pp. 55-65;

Carreño, Gonzalo y JaraQuemada, Jorge, La fuerza vinculante de las sentencias constitucionales y el reconocimiento de derechos fundamentales. A propósito de la ley sobre regulación de la fertilidad, en Revista Chilena de Derecho, 37 (2010), pp. 405-419;

CEA, José Luis, La jurisdicción constitucional, en Revista de Derecho de la Universidad Finnis Terrae, X (2006), pp. 11-19;

CEA, José Luis, Efectos de la declaración de inconstitucionalidad. Dificultades y desafios, en Actualidad Jurídica, 17 (2008), pp. 165-174;

CEA, José Luis, El proyecto de reforma constitucional sobre los efectos de las sentencias del Tribunal Constitucional sobre la justicia ordinaria, en Estudios Constitucionales, 3 (2005) 1, pp. 67-72;

Cоцомво, Juan, Las sentencias constitucionales: tipología y efectos, en Jurisdicción constitucional en Chile y América Latina: presente y prospectivas (Humberto Nogueira coord., Santiago, LexisNexis, 2005), pp. 263-291;

Cоцомво, Juan, El requerimiento de inaplicabilidad ante el Tribunal Constitucional, 
en Temas Actuales de Derecho Constitucional (Santiago, Editorial Jurídica de Chile, 2009), pp. 53- 74;

CORREA, Jorge, Inaplicabilidadporinconstitucionalidad en la jurisprudencia del Tribunal Constitucional (Santiago, AbeledoPerrot, 2011);

Couso, Javier y CodDou, Alberto, La naturaleza jurídica de la acción de inaplicabilidad en la jurisprudencia del Tribunal Constitucional: un desafio pendiente, en Estudios Constitucionales, 8 (2010) 2, pp. 389-430;

Cumplido, Francisco, Reforma constitucional y régimen politico, en ZÚÑIGA, Francisco (coord.) Reforma Constitucional (Santiago, LexisNexis, 2005), pp. 113-124;

Delaveau, Rodrigo, Fallo del Tribunal Constitucional sobre la pildora del dia después. Paternalismo y la dificultad contramayoritaria, en Actualidad Jurídica 18 (2008), pp. 55-68;

Fermandois, Arturo, Inaplicabilidad y control concreto del Tribunal Constitucional: enjuiciando la arbitrariedad en la aplicación de la ley, en Actualidad Jurídica, 9 (2008) 17, pp. 175-192;

Fermandois, Arturo, Efecto vinculante de las sentencias del Tribunal Constitucional: ¿mito o realidad?, en ZúÑIGA, Francisco (coord.) Reforma Constitucional (Santiago, LexisNexis, 2005), pp. 685-696;

FERNÁNDEZ, Miguel Ángel, La sentencia del Tribunal Constitucional, su eventual carácter vinculante y la inserción en las fuentes del Derecho, en Estudios Constitucionales, 4 (2006) 1, pp. 125-149;

Fundación Jaime Guzmán, A propósito del proyecto de ley sobre regulación de la fertilidad: la fuerza del precedente constitucional, en Ideas y Propuestas, 24, (22 de julio de 2009), pp. 1-11;

García, Ana María, Influencia de la acción de inaplicabilidad por inconstitucionalidad como nueva atribución del Tribunal Constitucional, en Revista de Derecho Público, 70 (2008), pp. 117-128;

GómEZ, Gastón, La reforma constitucional a la jurisdicción constitucional. El nuevo Tribunal Constitucional chileno, en ZúÑIGA, Francisco (coord.) Reforma Constitucional (Santiago, LexisNexis, 2005), pp. 651-684;

Hormazábal, Hernán, El Nuevo Tribunal Constitucional (Santiago, LexisNexis, 2006);

Jiménez, Guillermo y Marshall, Pablo, La pildora del día después y las potestades públicas, en Hemiciclo, 1 (2010) 2, pp. 45-66;

MaC-Clure, Lucas, Tribunal Constitucional y los derechos: La discusión pendiente, en Sierra, Lucas y MAC-Clure, Lucas, Frente a las mayorías. Leyes supramayoritarias y Tribunal Constitucional en Chile (s.e., Santiago, 2011), pp. 169-275;

Martínez, José Ignacio, La cuestión de inaplicabilidad como mecanismo de control de la interpretación de preceptos legales, en Romero, Alejandro, Martínez, José Ignacio y Arancibia, Jaime (coords.), Litigación Pública (Santiago, AbeledoPerrotThomsonReuters, 2011) pp. 375-396;

Massman, Nicolás, La admisibilidad del recurso de inaplicabilidad: a tres años de la reforma, en Ius et Praxis, 15 (2009) 1, pp. 263-293;

Memoria 2007-2008 Del Tribunal Constitucional, disponible en http://www. tribunalconstitucional.cl/index.php/documentos/downloadpdf/301;

Nash, Claudio e Irarrázabal, Paz, Justicia constitucional en Chile y protección de los derechos fundamentales, en BAZÁN, Víctor y NASH, Claudio (edits.), Justicia Constitucional y Derechos Fundamentales. Aportes de Argentina, Bolivia, Brasil, Chile, 
Perú, Uruguay y Venezuela 2009 (Santiago, Konrad Adenauer Stiftung y Centro de Derechos Humanos de la Facultad de Derecho de la Universidad de Chile), pp. 55-67, disponible en http://www.cdh.uchile.cl/libros/Libro_Justicia_Constitucional.pdf;

Navarro, Enrique, El control de constitucionalidad de las leyes en Chile (1811-2011), (Santiago, Cuadernos del Tribunal Constitucional, 43, 2011);

NogueIRA, Humberto, El control represivo concreto y abstracto de inconstitucionalidad de leyes en la reforma de las competencias del Tribunal Constitucional y los efectos de sus sentencias, en Estudios Constitucionales, 3 (2005) 1, pp. 11-35;

Nogueira, Humberto, La sentencia del Tribunal Constitucional en Chile: análisis y reflexiones juridicas, en Estudios Constitucionales, 8 (2010) 1, pp. 79-116;

NúÑEZ, Manuel, El control de la igualdad en la aplicación de la ley como factor de expansión del control concreto de constitucionalidad de las leyes, en Sentencias Destacadas 2007 (Santiago, Instituto Libertad y Desarrollo, 2008), pp. 123-161;

PeÑA, Marisol, El precedente constitucional emanado del Tribunal Constitucional y su impacto en la función legislativa, en Estudios Constitucionales, 4 (2006)1, pp. 173184;

PICA, Rodrigo, El carácter concreto del control de inaplicabilidad de la ley en el derecho chileno, en Revista de Derecho Universidad Católica del Norte, 16 (2009) 2, pp. 101-136;

Piedrabuena, Guillermo, Control judicial anterior a la formalización de la investigación (artículo 186 del Código Procesal Penal), en Revista de Derecho Consejo de Defensa del Estado 23 (2010), pp. 9-38, disponible en http://www.cde.cl/wps/wcm/conne ct/2c1c5b80456a3f789b2a9b32d05f89d2/Rev+23_5+control+judicial+anterior $+\mathrm{a}+\mathrm{la}+$ formalizacion+de+la+investigacion.pdf?MOD=AJPERES;

Recopilación de jurisprudencia del Tribunal Constitucional (19812011), (Enrique Navarro y Carlos Carmona editores, Santiago, Cuadernos del Tribunal Constitucional, 2011);

Ríos, Lautaro, Trascendencia de la reforma constitucional en la fisonomia y las atribuciones del Tribunal Constitucional, en Gaceta Jurídica 299 (2005), disponible en http:// productos.legalpublishing.cl;

Rodríguez, Pablo, Constitucionalización del derecho, en Actualidad Jurídica 22 (2010), pp. 9-20;

SAENGer, Fernando, Acción de inaplicabilidad e inconstitucionalidad. Facultades del nuevo Tribunal Constitucional. Algunos casos jurisprudenciales, en Estudios Constitucionales, 5 (2007) 1, pp. 305-348;

SAlazar, Marta, Interpretación de la Constitución y control de la ley interpretativa por el Tribunal Constitucional, en Revista Chilena de Derecho, 20 (1993) 2-3, pp. 467-473;

Silva, Alejandro, Tratado de Derecho Constitucional (Santiago, Editorial Jurídica de Chile, 1997), I;

Silva, Luis Alejandro, El control de constitucionalidad de los actos administrativos legales (Santiago, LegalPublishing, 2009);

Silva, Luis Alejandro, El control de legalidad del Tribunal Constitucional: dice pero no hace. Comentario a la sentencia del Tribunal Constitucional Transantiago II, rol 1.153, de 30 de septiembre de 2008, en Ius et Praxis, 15(2009) 2, pp. 319-330;

SKoKnic, Ivo, Justicia Constitucional, (2009), disponible en http://www.westlaw.cl [última consulta el 8 de febrero de 2012]; 
Verdugo, Mario, Efectos vinculantes de los precedentes del Tribunal Constitucional en la actividad de la Contraloría General de la República, en Estudios Constitucionales, 4 (2006) 1, pp. 223-231;

Verdugo, Sergio, Inaplicabilidad y vicios de forma. ¿Un problema resuelto?, en Revista de Derecho Universidad Austral de Chile, XXIII (2010) 2, pp. 83-112;

Verdugo, Sergio, El nuevo "round" entre el TC y los Tribunales Superiores: Dificultad ineludible del modelo de cohabitación kelseniano, (2011) disponible en http://diarioconstitucional.cl/mostrararticulo.php?id=101;

Zapata, Patricio, Justicia Constitucional. Teoría y Práctica en el Derecho chileno y comparado (Santiago, Editorial Jurídica de Chile, 2008);

Zapata, Patricio, Las sentencias atípicas en la jurisprudencia del Tribunal Constitucional chileno, en Estudios Constitucionales, 4 (2006) 2, pp. 175-187;

ZúÑIga, Francisco, Control de constitucionalidad y casación, en Anuario Iberoamericano de Justicia Constitucional, 10 (2006), pp. 335-380;

ZúNiga, Francisco, Control de constitucionalidady sentencia (Santiago, Cuadernos del Tribunal Constitucional 34, 2006);

ZúñIga, Francisco [Comentario a la sentencia rol 740 del TC], en Revista de Derecho Público, 70 (2008), pp. 471-487;

Zúñıga, Francisco, Acciones de inaplicabilidad e inconstitucionalidad. Doctrina y jurisprudencia del Tribunal Constitucional sobre temas procesales (Santiago, LegalPublishing, 2010);

ZúÑIGa, Francisco, Acción de inaplicabilidad por inconstitucionalidad: requerimiento de jueces entre legalidad y constitucionalidad, en Revista de Derecho Público, 72 (2010), pp. 294-339.

Jurisprudencia consultada:

Sentencia de la Corte de Apelaciones de Santiago, Peña Wasaff con Isapre ING Salud S.A., rol 4972-2007, 24 de septiembre de 2008

Sentencia de la Corte de Apelaciones de Santiago, Vera Flores con Subcontralora General de la República, rol 8777-09, 29 de octubre de 2009

Sentencia de la Corte Suprema, Sergio Toloza Rodríguez con Jueces del Juzgado de Familia de Osorno, rol 6626-2006, 24 de junio de 2008

Sentencia de la Corte Suprema, Bitterlich con Isapre Colmena Golden Cross, rol 7779-2008, de 26 de octubre de 2009

Sentencia de la Corte Suprema, Andrade Fuentes con Isapre Masvida S.A., rol 4881-2010, de 24 de septiembre de 2010

Sentencia de la Corte Suprema, Gómez Montoya con Corporación Administrativa del Poder Judicial, rol 4518-2011, 30 de noviembre de 2011

Sentencia de la Corte Suprema, SII con No se consigna, rol 8424-09, 19 de diciembre de 2011

Sentencia de la Corte Suprema Federal de los Estados Unidos, Cooper v. Aaron 358 U.S. 1 (1958).

Sentencia de la Corte Suprema Federal de los Estados Unidos, Marbury v. Madison, 5 U.S. 137 (1803).

Pronunciamiento del Tribunal Pleno de la Corte Suprema rol 1450-2002, de 19 de junio de 2002

Dictamen de la Contraloría General de la República Nº 31.356, de 16 de junio de 2009 
Resolución del Tribunal Constitucional rol 793, de 17 de julio de 2007 Sentencia del Tribunal Constitucional rol 472, de 30 de agosto de 2006 Sentencia del Tribunal Constitucional rol 591, de 11 de enero de 2007 Sentencia del Tribunal Constitucional rol 681, de 26 de marzo de 2007 Sentencia del Tribunal Constitucional rol 736, de 29 de noviembre de 2007

Sentencia del Tribunal Constitucional rol 740, de 18 de abril de 2008

Sentencia del Tribunal Constitucional rol 747, de 31 de agosto de 2007 Sentencia del Tribunal Constitucional rol 755, de 31 de marzo de 2008 Sentencia del Tribunal Constitucional rol 806, de 11 de diciembre de 2007

Sentencia del Tribunal Constitucional rol 810, de 24 de enero de 2008 Sentencia del Tribunal Constitucional rol 815, de 19 de agosto de 2008 Sentencia del Tribunal Constitucional rol 815, de 19 de agosto de 2008. Sentencia del Tribunal Constitucional rol 976, de 26 de junio de 2008 Sentencia del Tribunal Constitucional rol 1220, de 16 de septiembre de 2008

Sentencia del Tribunal Constitucional rol 1191, de 19 de mayo de 2009

Sentencia del Tribunal Constitucional rol 1284, de 24 de septiembre de 2009

Sentencia del Tribunal Constitucional rol 1287, de 8 de septiembre de 2009

Sentencia del Tribunal Constitucional rol 1288, de 25 de agosto de 2009

Sentencia del Tribunal Constitucional rol 1295, de 6 de octubre de 2009

Sentencia del Tribunal Constitucional rol 1341, de 15 de abril de 2010

Sentencia del Tribunal Constitucional rol 1489, de 5 de octubre de 2010

Sentencia del Tribunal Constitucional rol 1615, de 20 de enero de 2011

Sentencia del Tribunal Constitucional rol 1710, de 6 de agosto de 2010

Sentencia del Tribunal Constitucional rol 1801, de 12 de abril de 2011

Sentencia del Tribunal Constitucional rol 2025, de 20 de julio de 2011

Otras fuentes:

Historia de la reforma de la Ley Orgánica del Tribunal Constitucional, $\mathrm{N}^{\circ} 20.381$, disponible en http://www.bcn.cl/histley/periodos?p=2009

Segundo Informe de la Comisión de Constitución, Legislación y Justicia del Senado, 15 de enero de 2007, Boletín 4059-07, disponible en http://www.senado.cl/appsenado/ templates/tramitacion/index.php\# 